\title{
التعدية من منظور لساني
}

د. صالح أحمد صافار

\section{جامعة مصراتة}

\section{تمهيد: - n}

مسألة التعدية التي درسها النحويون دراسة مستفيضة مـن حيث التركيب "الجانب

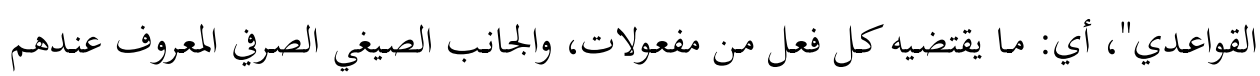

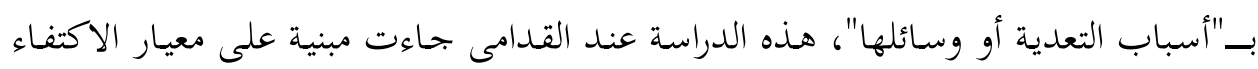

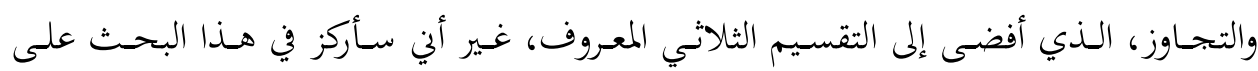

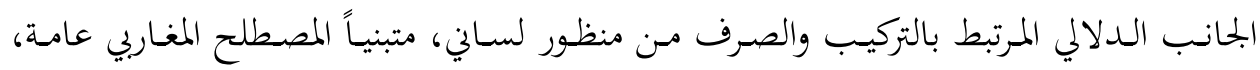

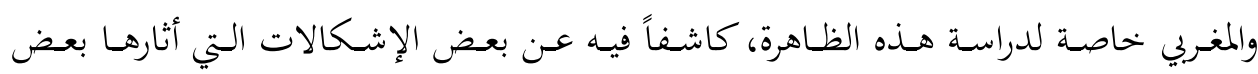

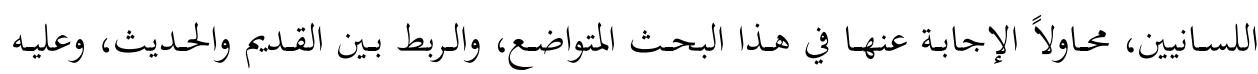
سيكون مفهوم التعدي- في هذا المبحث - مختلفاً عن مفهومه عند النحويين، كما أني سأتناول

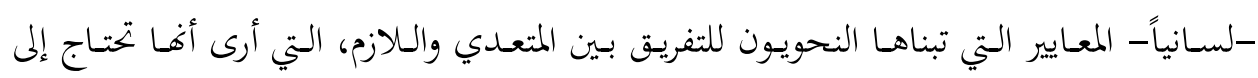
وقفات أخر.

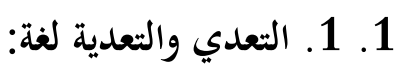

التجاوز: قال ابن منظور (( التعدي: بحاوزة الشيء إلى غيره، يقال: عدّيته فتعدّى: إذا

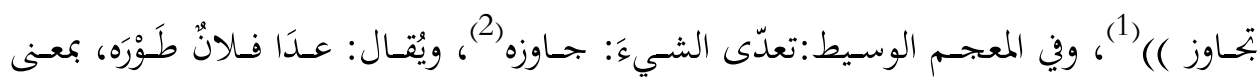

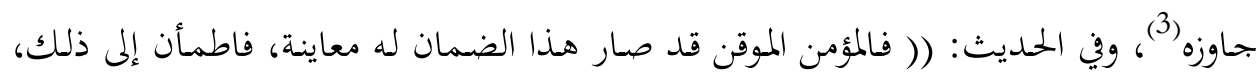

$$
\begin{aligned}
& \text { 1 - لسان العرب "عدو" 711/4. } \\
& \text { 2- 2 ينظر 589/2. } \\
& \text { 3- ينظر معجم مقاييس اللغة "طور" 81/2 و "عدو" 230/2. }
\end{aligned}
$$


ولم يتعـد إلى الحـرام، والذي ضعُف يقينه بغلبـة شهواته على إيمانه، فيفتـن ويتعدّى إلى الحـرام

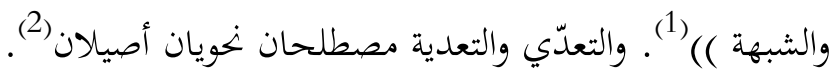

\section{1-2-1. اصطلاحاً:}

عرّف الرُّماني التعدية بقوله: (( التعدية هي التي تسلط العامل على مـا بعدها حتى

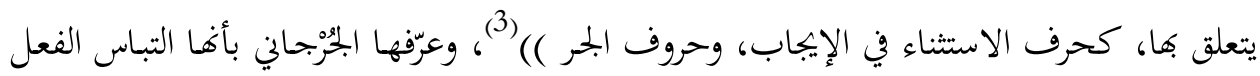

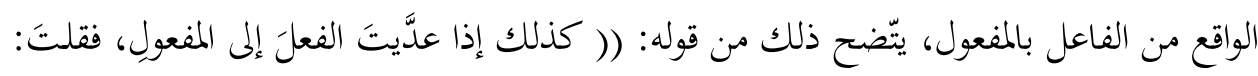

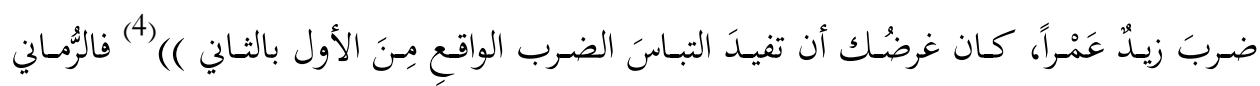

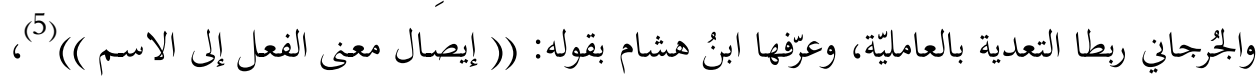

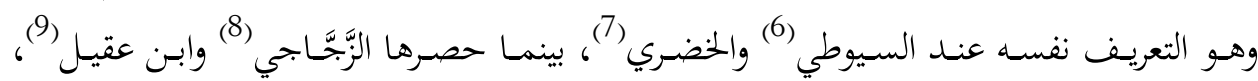
والصبّان(10)، في نصب المفعول به، وعرّفها الزَّخشري بقوله: (( جعل الشيء متعدياً )) (11).

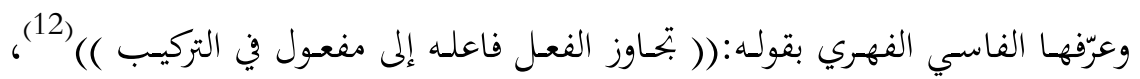

وعرّفها البعلبكي بقوله: (( كون الفعل متعدياً )) (13).

1- نوادر الأصول في أحاديث الرسول، محمد الترمذي: باب في أخلاق المعرفة 16/4.

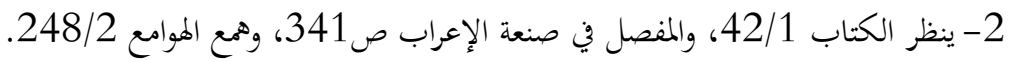

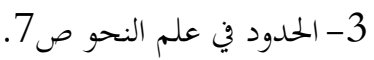

4- دلائل الإعجاز صـ 127 .

5- مغني البيب ص578.

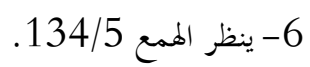

7-

8- شرح جمل الزجاجي 273/1.

9- ينظر شرح ابن عقيل 533/1.

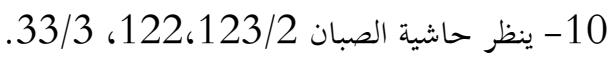

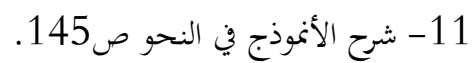

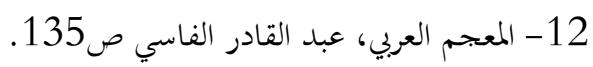

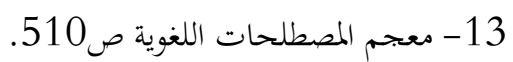


ويرى بعض المحدثين أن الصبان فرّق بين التعدي والتعدية، حيث عدَّ باء التعدي عامة وباء

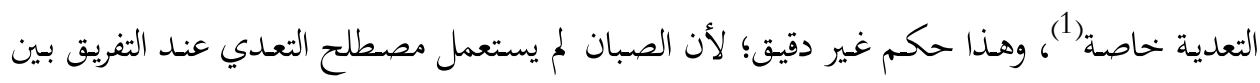

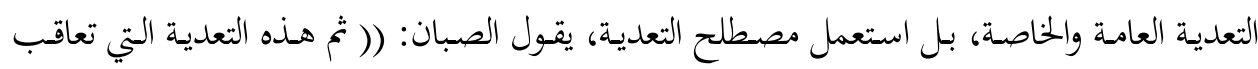

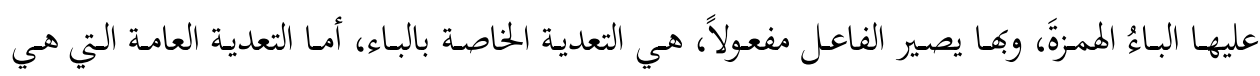

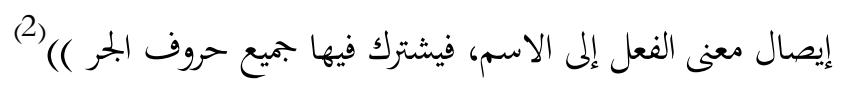

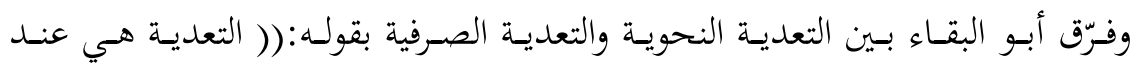

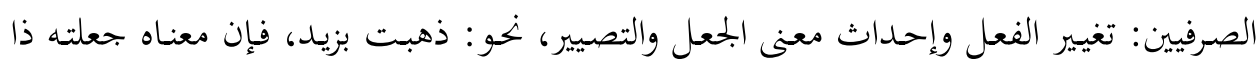
ذهاب أو صيرته ذا ذهاب، وعند النحاة هي: إيصال معاني الأفعال إلى الأسماء )) (3).

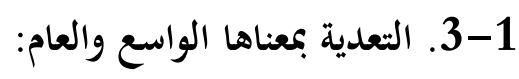

ذكر النحاة أن الفعل المتعـدي واللازم يشتركان في التعـدي، يقول سيبويه: (( واعلم أنَّ

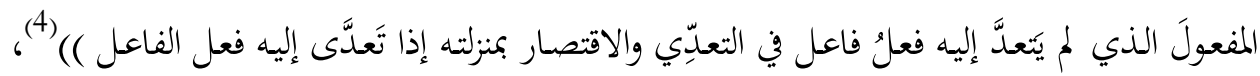

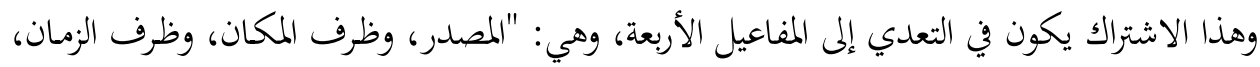
والحال"، يقول ابن يعيش: (( الفعل الذي لا يتعدى الفاعل والذي يتعداه جميعاً يشتركان في التعدي

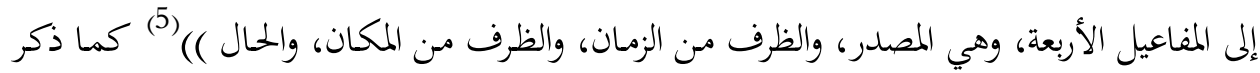

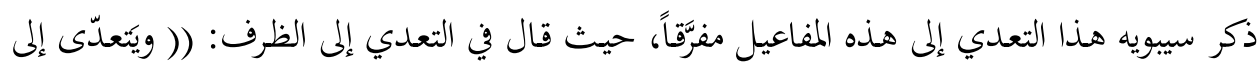

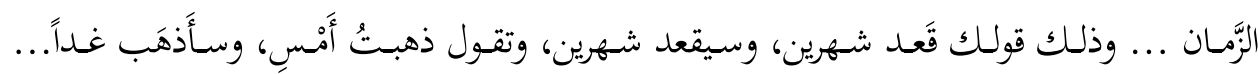

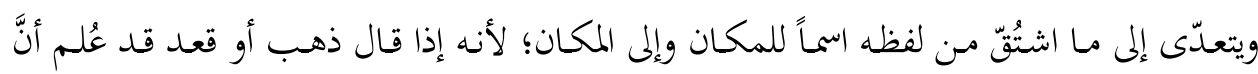
للحدث مكاناً، وإن لم يَذكره كما عُلم أنه قد كان ذهابِ، وذلك قولك: ذَهبتُ المذهـبَ البعيدَ،

$$
\begin{aligned}
& \text { 1- ينظر الجملة العربية "دراسة لسانية" عبد العزيز العماري ص109. } \\
& \text { 2- حاشية الصبان 126/2. } \\
& \text { 3- الكليات صانشية الصبان } \\
& \text { 4- الكتاب 1/ 42، وينظر الأصول في النحو 170/1. } \\
& \text { 5- شرح المفصل 67/7. }
\end{aligned}
$$


وجَلستُ بحلساً حسناً وقَعْْتُ مقعداً كريماً، وقعذْتُ المكانَ الذي رأيت )( (1)، كما ذكر التعدي إلى الحال فقال: (( فعَملُ الفعلِ هنا فيما يكون حالاً كعمل مثله فيما بعده، ألا ترى أنه لا يكون

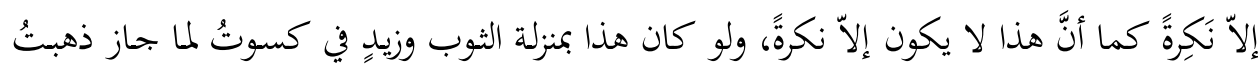

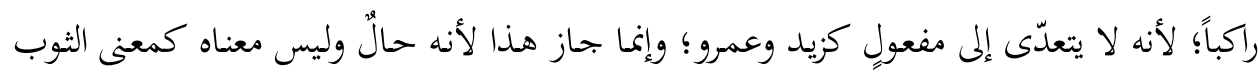

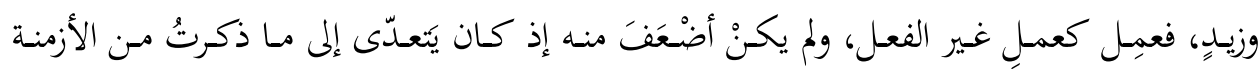

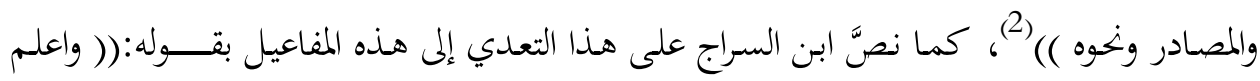

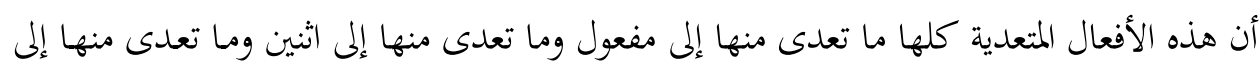

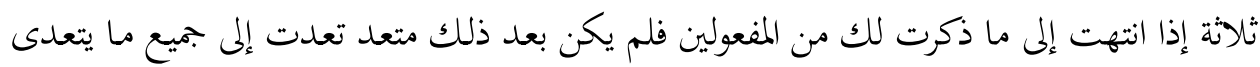
إليه الفعل الذي لا يتعدى الفاعل إلى مفعول من المصدر والظرفين والحال )( (3). وهذا النوع من التعدي لا يعنينا في البحث، وإنما الذي يعنينا هو التعدي إلى المفعول به، من حيث عدد المفعولات الذي حصره النحويون قي ثلاثة أقسام على أساس التجاوز، كما

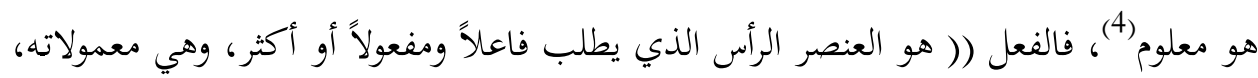

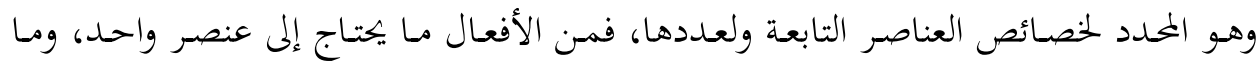

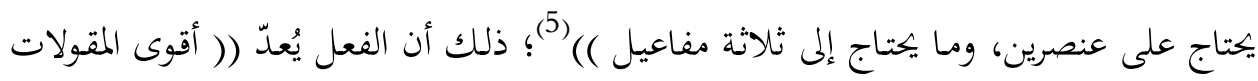

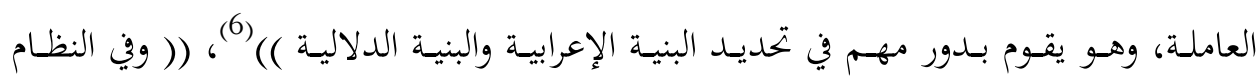

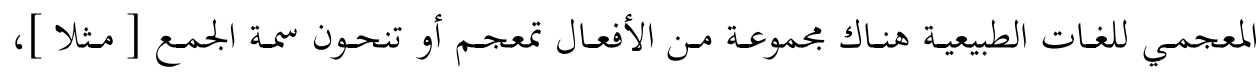

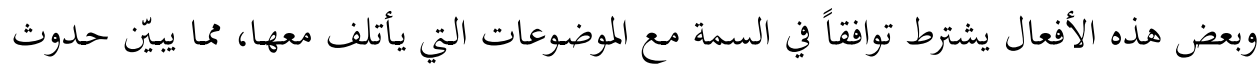

$$
\begin{aligned}
& \text { 1- الكتاب 35/1. } \\
& \text { 2- المصدر السابق 44/1-45-4 }
\end{aligned}
$$

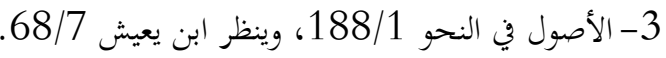

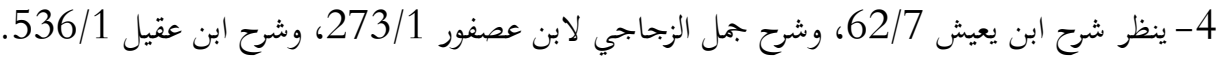

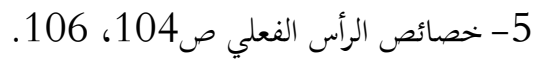

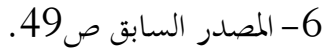


نوع من الفحص لسمات متجانسة في التركيب، فمثلاً تقول هطلت الأمطار، بينما لا يجبوز أن

$$
\text { تقول:* هطلت قطرة () (1). }
$$

\section{2-1-1 مصطلحات لسانية:}

قبل الخوض في الجزئية الآنفة الذكر -التي أرى أن فيها شيئاً من الخلط وعدم الشمولية في الأحكام التي قعّدها النحويون- لابد لي من تعريف بعض المصطلحات اللسانية التي سترد في هذا البحث، حتى يستطيع القارئ التواصل معي، وهذه المصطلحات هي:

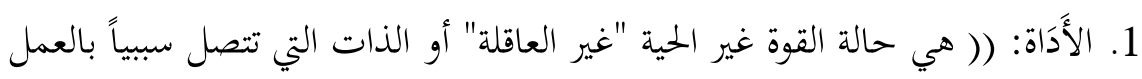

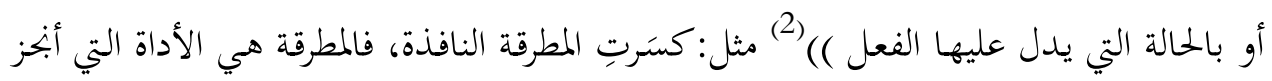
بها الكسر. 2. أَوَاسِط: جمع "واسطة"وهي: لواصق تكون داخل الكلمة أو وسطها لتغير معناهـا،

$$
\text { كألف "ناضل" (3). }
$$

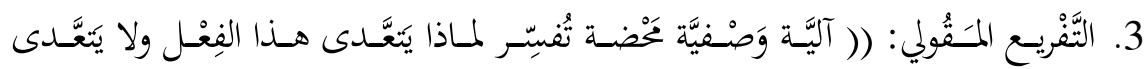

$$
\text { ذلك؟ () (4) }
$$

4. الانتقـاء المَقُولي: (( قاعـدة تحـدد مـا يشـترطه المحمـول "أي الفعل" في موضـوعاته مـن سمـات )) (5)، أي: أن هـذه (( الموضـوعات يجـب أن تستجيب لماء يشـترطه المحمسول فيهـا، فالفعـل

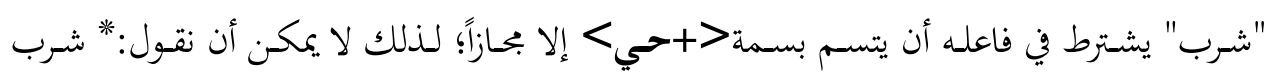

$$
\begin{aligned}
& \text { 1- الزمن في اللغة العربية، امحمد الملاخ ص166، وينظر ص207. }
\end{aligned}
$$

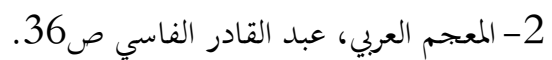

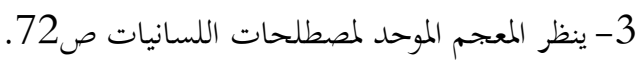

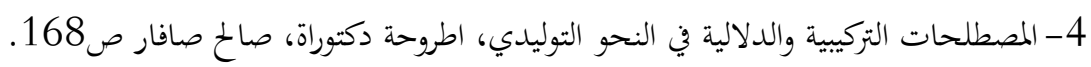

$$
\begin{aligned}
& \text { 5- خصائص الرأس الفعلي ص386. }
\end{aligned}
$$


المصباح كذا )) (1)، وتسمى هذه: قيود الانتقاء، أو قيود انتقائية (( ووظيفة هذه القيود الحصول على القراءة التي تتلاءم ومعاني الألفاظ المكونة للجملة، فكل مـدخل معجمي إذن مخصص بقدي لميود انتقاء

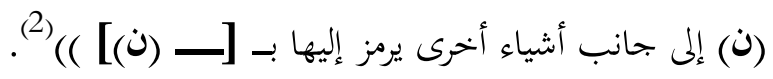

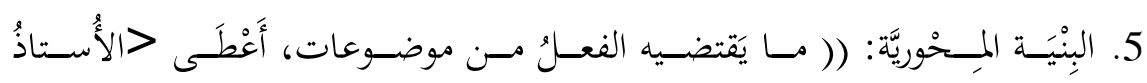

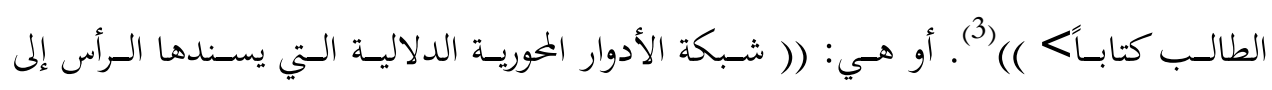
موضوعاته () (4)

6. بِنْيَة مَوضُوعيَّة: (( البنيـة الـتي تعكس عـدد الموضـوعات الـتي يقتضسيها الفعـل، مثل:كتَبَ الطالب الدرس، حيث يقتضي الفعل موضوعين، يكون الموضوع الأول "الطالب" هو القائم بالحدث، ويكون الموضوع الثاني "الدرس" هو الذي وقع عليه الفعل )(5).

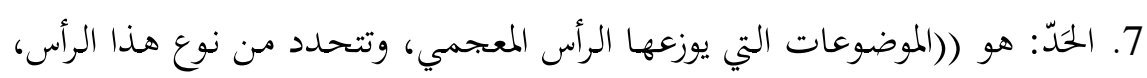

فالرأس اللازم يطلب حدّاً واحداً، والرأس المتعدي يطلب أكثر من حدّ )) (6).

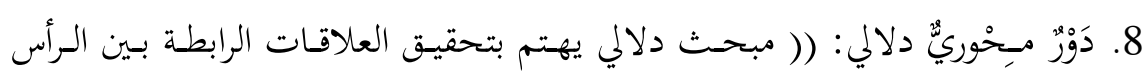

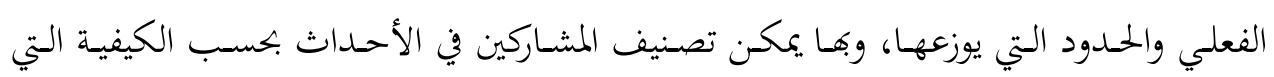

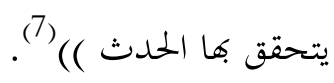

1- مدخل إلى الدلالة الحديثة، عبد البجيد جحفة ص62، بتصرف قليل وينظر : المصطلحات التركيبية والدلالية في

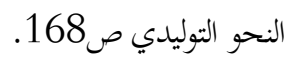
2- مدخل إلى الدلالة الحديثة ص83، التهوي بتصرف قليل.

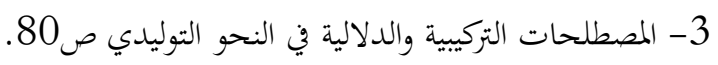

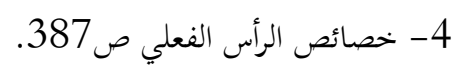

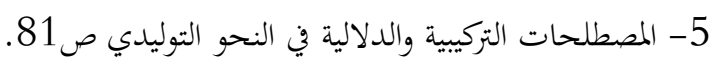

$$
\text { 6- 7- خصائص الرأس الفعلي ص1407. }
$$




$$
\text { 9. الرَائز أو الرَّوز: التجربة(1). }
$$

10. الرأس الفِعْلي:(( العنصر الذي يرد في صدر الجملة الفعلية، ويمالأ الموضع الأول

$$
\text { فيها () (2) }
$$

11. الرأس المُعْجَمي: (( هـو العنصر المعجمي الذي يتصدر التركيب، وينتمي إلى

\section{مفهوم الأساس في النظام النحوي ()) (3).}

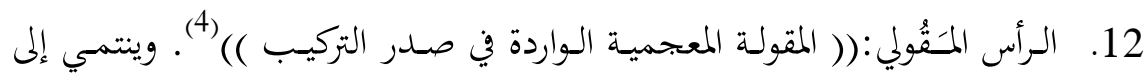
مفهوم الأساس في النظام النحوي.

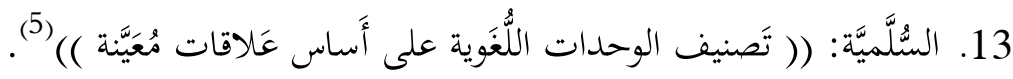

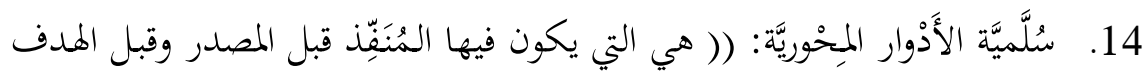

$$
\text { أو الضَّحيَّة () (6) }
$$

15. سُلَّميَّة الوظـائف الإعرابيـة: هـي الـتي يكـون فيهـا الفاعـل قبـل المفعـول الأول

$$
\text { والمفعول الأول قبل الثاني (7). }
$$

16. سَوابِق: جمع "سابقة" وهي: (( لَواصِق تقع في بداية الكلمات تؤدي وظائف

$$
\text { نحوية ودلالية مختلفة، مثل: ياء المضارع في يكتب ()(8). }
$$

1 - 1 ينظر: اللسانيات واللغة العربية، للفاسي الفهري 14/1.

$$
\begin{aligned}
& \text { 2- خصائص الرأس الفعلي ص387، 387، بتصرف قليل. } \\
& \text { 3- المصدر السابق ص388. }
\end{aligned}
$$$$
\text { 4- المصدر السابق ص388. }
$$

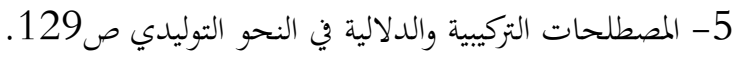

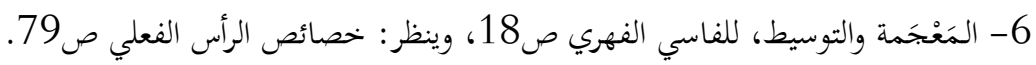

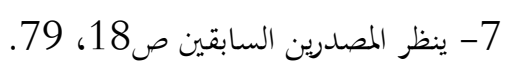

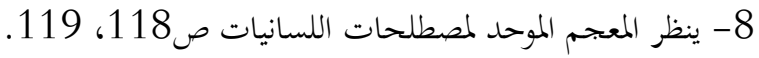


17. شَبَكة الأَدْوار المِسحورَيَّة: (( هي قائمة الأدوار المحورية الدلالية غير المنتظمة التي

يعينها رأس معجمي لحدوده، وهي تستمد من المعنى المعجمي للرأس الفعلي )) (1).

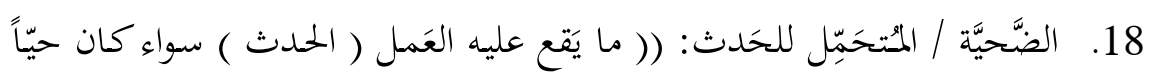

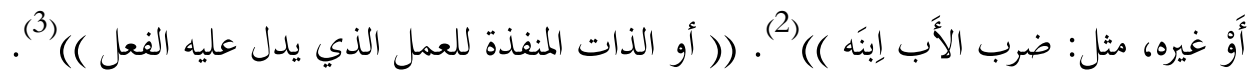
(3) $(($

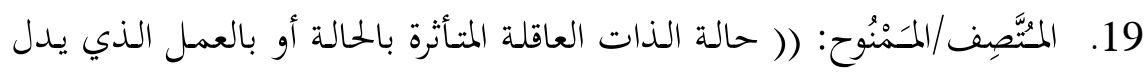

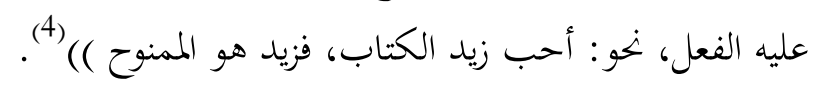

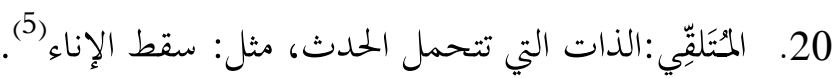

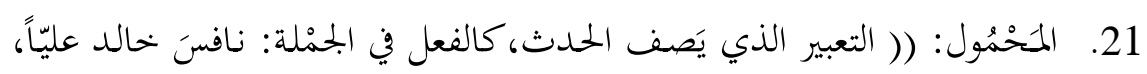

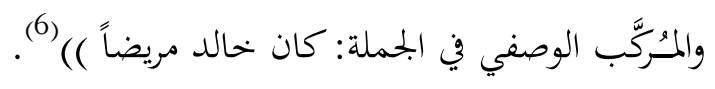

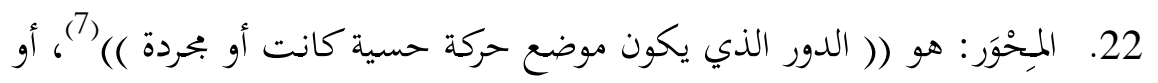

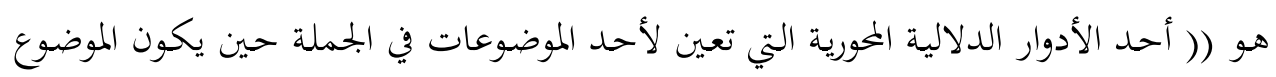

شيئاً معط اهتمام المجرِبِ، كما في: أحبّ الطفل الكرة، فالكرة محور )) (8).

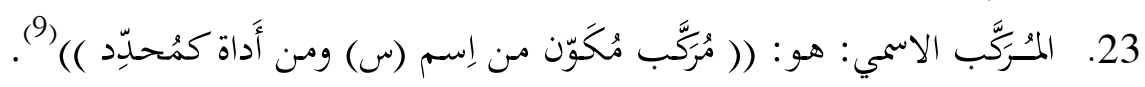

أو هو (( مركب يدل دلالة معجميّة ويحيل إلى ذات )) (1).

1- المعجم الموحد لمصطلحات اللسانيات ص388.

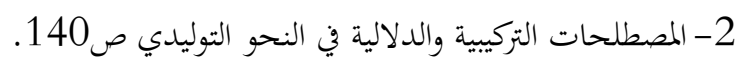

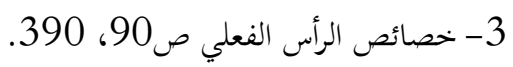

$$
\begin{aligned}
& \text { 4- المصدر السابق ص60. }
\end{aligned}
$$

5- ينظر : نظرية النحو الوظيفي، محمد مليطان ص126.

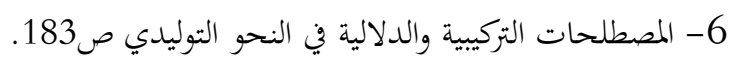

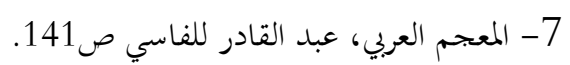

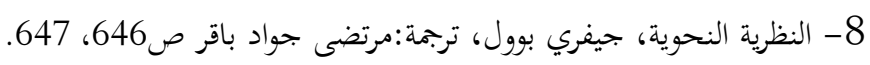

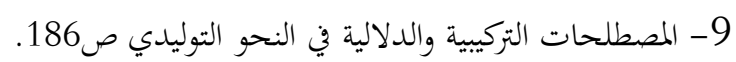


24. المهركَّبَ الوصْفي: ( ما اشتَمل على كَلِمتيْن أَوْ أَكثر تَكُون الثانية ناعتِة لدَلالة

$$
\text { الأُولى، مثل: كتاب جِيّد () (2). }
$$

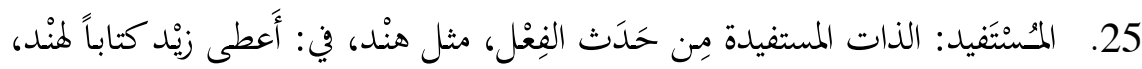

وكتبت هند رسالة لعمرو، فعمرو هو المستفيد، ونحو: حصل زيد على هدية، فزيد مستفيد (3).

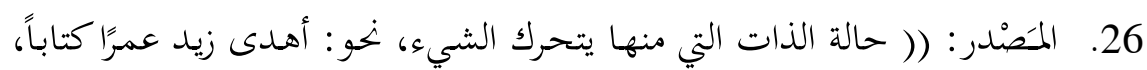

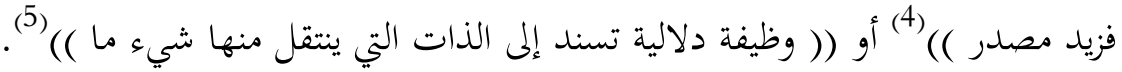

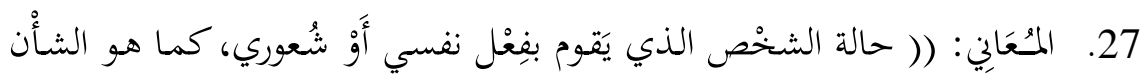

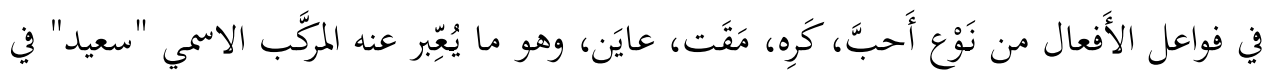

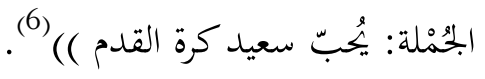

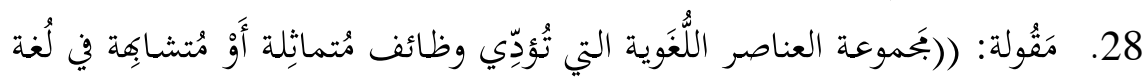

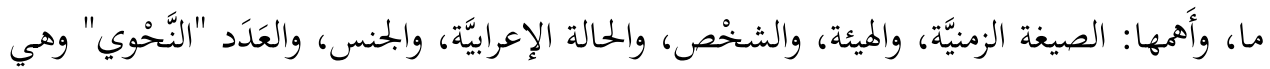

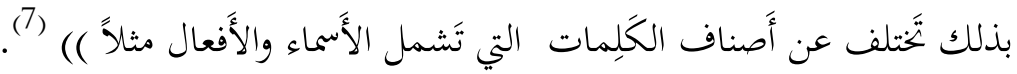

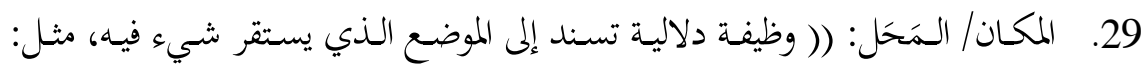

$$
\text { تسكن هند بمدينة طرابلس () (8). }
$$

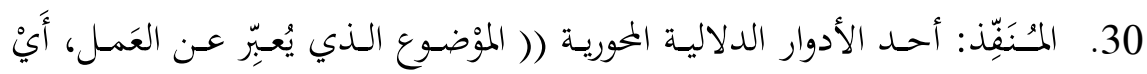

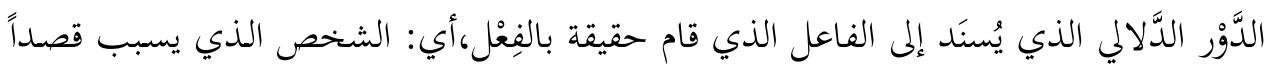

$$
\text { 10- نظرية النحو الوظيفي ص134. }
$$

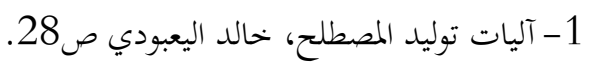

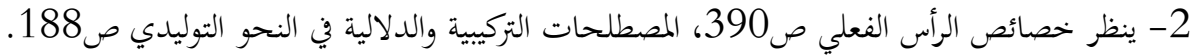

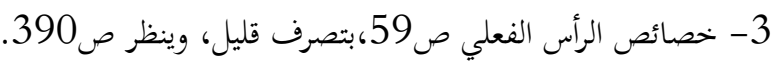

$$
\begin{aligned}
& \text { 4- نظرية النحو الوظيفي ص137. }
\end{aligned}
$$

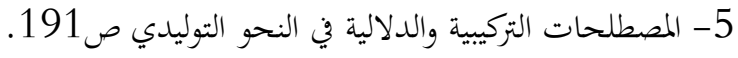

$$
\text { 6- المصدر السابق ص196. }
$$

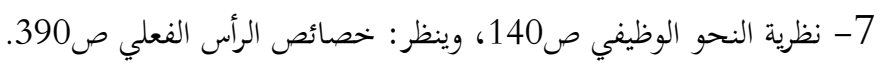


الحلدث، وذلك في مثل: كتب الطالب الدرس، فالطالب فاعل مُنفِّن بخِلاف: مَرِض زيْد، فزيْد

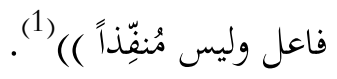

31. المَوْوبوع: (( الأسماء أو المركبات الاسمية التي يأخذها الفعل في الجملة، فمثلاً:

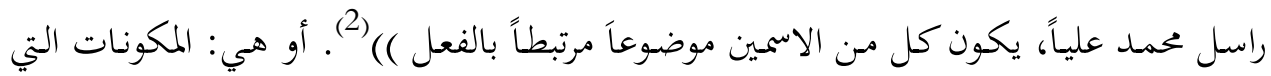
تتركب مع الفعل، وتسمى: بنية موضوعية.

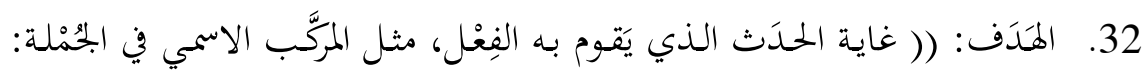

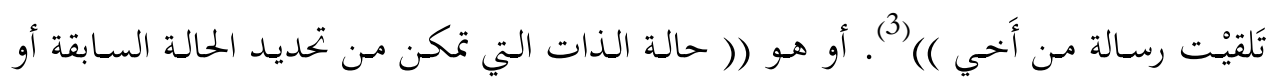

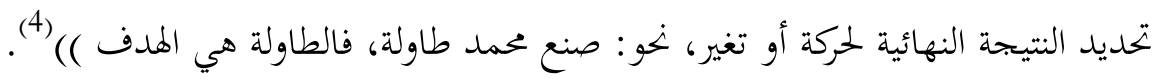
3. 1 1. معايير التعدية:

وضع بعض النحويين معايير للأفعال المتعدية، ويمكن تقسيم هذه المعايير إلى: 3. 1. 1. 1. معايير دلالية: ويقصد بما:

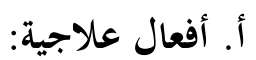

ما يفتقر في إيجادها إلى استعمال جارحة أو نهوها، مثل: ضربت زيداً، وتدخل أفعال الحواس في هذا النوع، كشمَّ، وأبصر، وذاق، ولمس، وسمع، يقول ابن يعيش: (( والمتعدي يكون

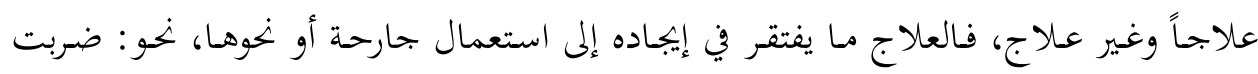

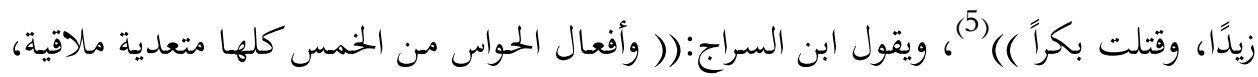

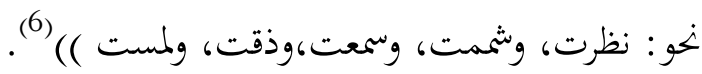

1- نظرية النحو الوظيفي ص202، وينظر: المعجم العربي، عبد القادر الفاسي ص36، وخصائص الرأس الفعلي

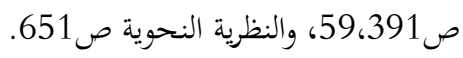

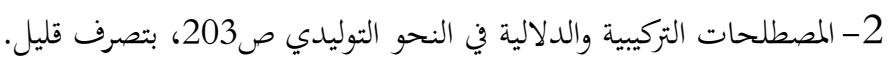

$$
\begin{aligned}
& \text { 3- المصدر السابق ص215. }
\end{aligned}
$$

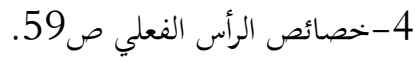

$$
\begin{aligned}
& \text { 5- شرح المفصل 62/7. } \\
& \text { 6- الأصول في النحو 170/1. }
\end{aligned}
$$




\section{ب. أفعال غير علاجية:}

ما لم يفتقر إلى استعمال جارحة أو نحوها، بل يكون مما يتعلق بالقلب مثل: ذكرت زيداً،

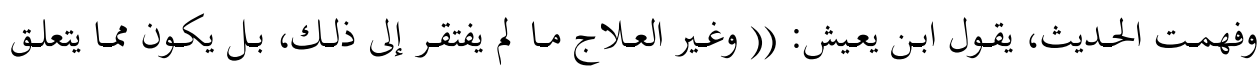

$$
\begin{aligned}
& \text { بالقلب، نحو ذكرت زيداً وفهمت الحديث )( (1). } \\
& \text { ج. أفعال مؤثرة: }
\end{aligned}
$$

وهي الأفعال التي تنفذ من الفاعل إلى المفعول وتؤثر فيه مثل: كسا وأعطى، يقول ابن

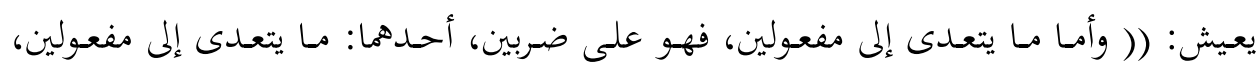

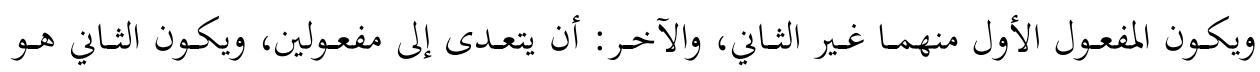

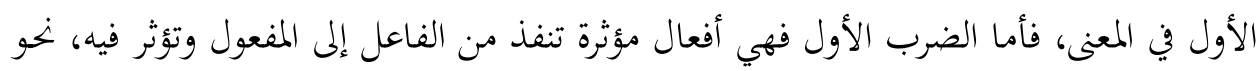

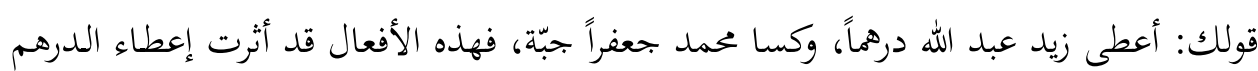

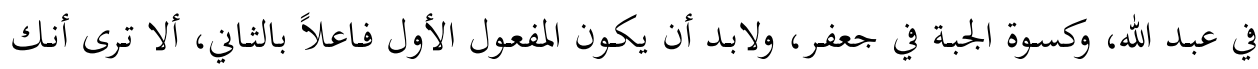

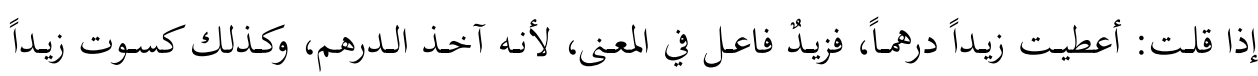

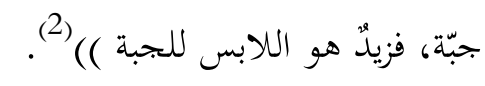

\section{1. 2. 2. معايير صرفية:}

اعتمد النحاة على المعيار الصرفي في الحكم على بعض الأفعال بالتعدي، وذلك بزيادة

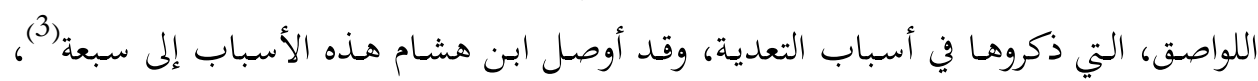
وتتمظهر هذه اللواصق في:

أ. زيادة السابقة "الهمزة": فَعَلَ ـ ـأَفْعَل، مثل: أخرجت زيداً. ب. التضعيف: فَعَلَ ـ ـ فَّل، مثل: فرّحت الطفلَ.

$$
\text { 1- 1- شرح ابن يعيش 62/7. }
$$

3- ينظر مغني اللبيب ص678، وينظر المكرابق المفصل في صنعة الإعراب ص341، حيث سماها الزخشري أسباب التعدية، وذكر ثلاثة. 
ج. زيادة الواسطة "الألف": فَعَلَ ـ ـَاعَل، مثل: جالست العلماء.

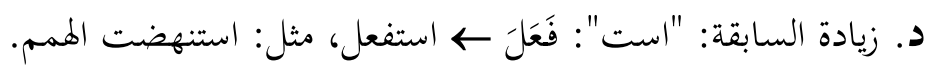
ويرى بعض اللسانيين أن هذه المعايير لا تنطبق على كل الأفعال، وأن تركيز النحويين على الجانب الصرفي الصيغي غير دقيق لعدم شموليته، حيث يمكن أن ترد بعض أسباب التعدية في سياق يكون الفعل فيه لازماً، يقول العمّاري: (( أول ملاحظة تثير الانتباه هي أن النحاة

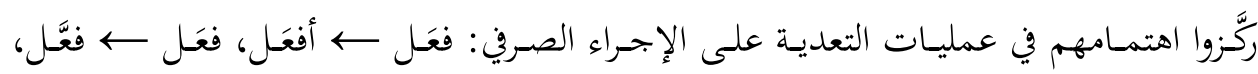

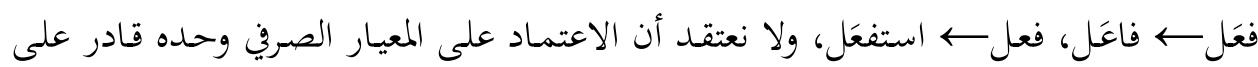

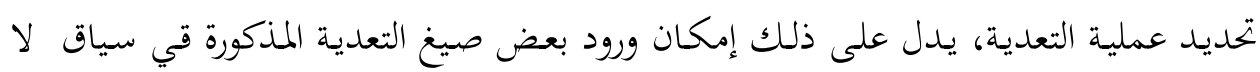

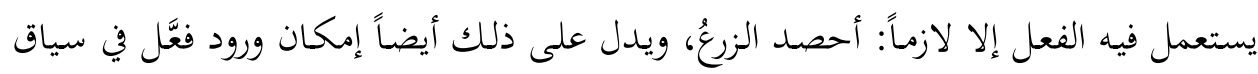

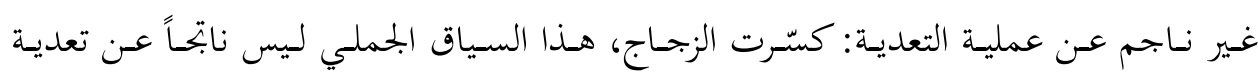

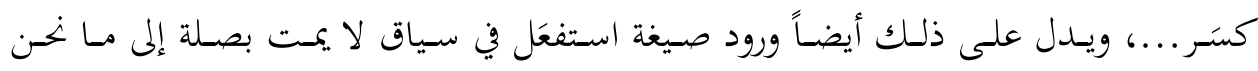

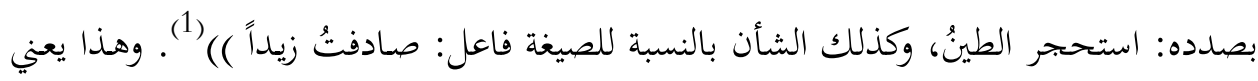
أن المعيـار الصريف الذي اعتمـده النحويون غير كاف للحكمى على الأفعال مـن حيث التعدية

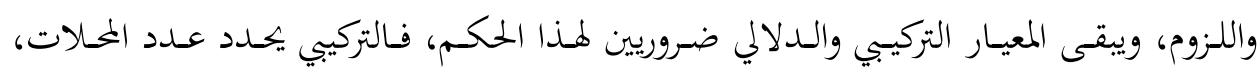
والدلالي يقوم بعملية الانتقاء للوصول إلى الانسجام بين التركيب والدلالة، نتيجته بنية سليمة غير لاحنة.

غير أن هذا الاعتراض اللساني غير دقيق؛ لأن النحويين لم يقولوا إن كل ماكان على

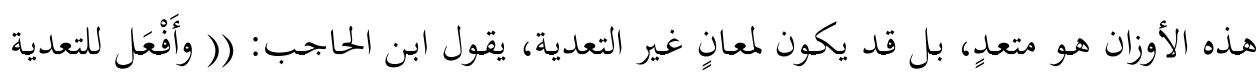

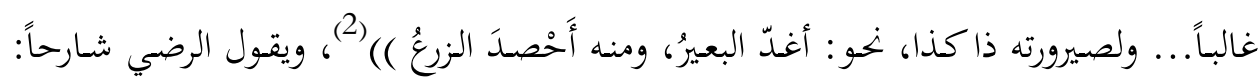

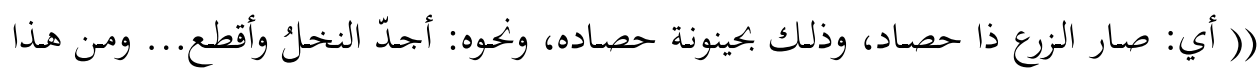

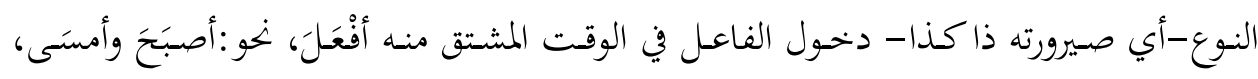

$$
\text { 2- ش- شرحلة العربية صافية ابن الحاجب للرضي 100، 83/1. }
$$




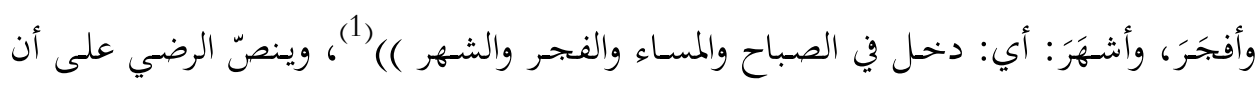

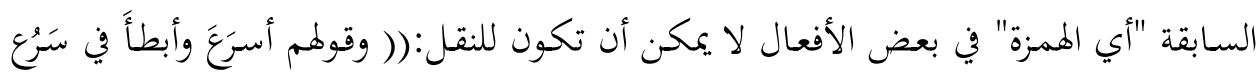

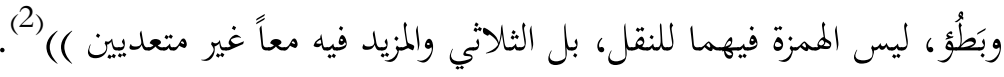

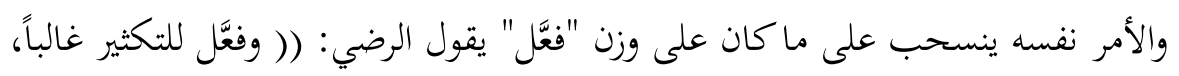

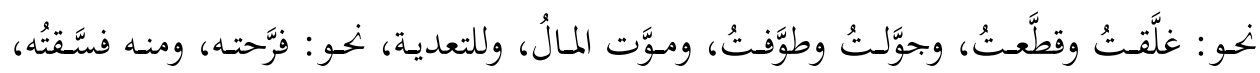

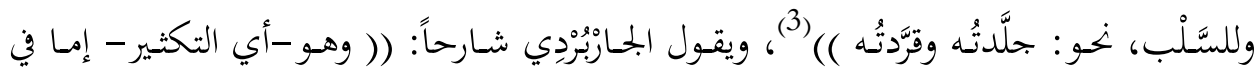

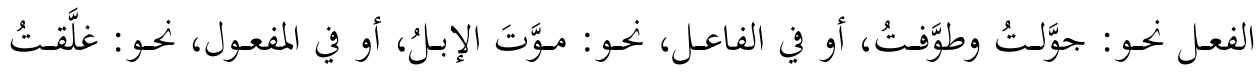

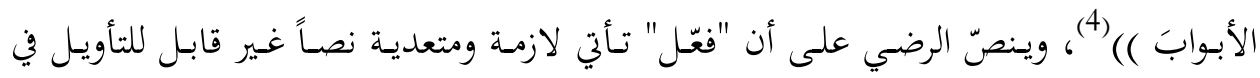

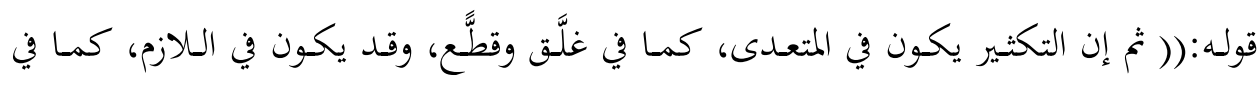

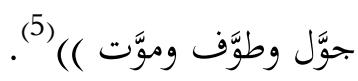

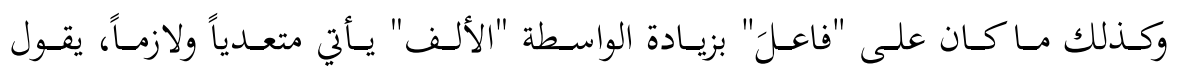

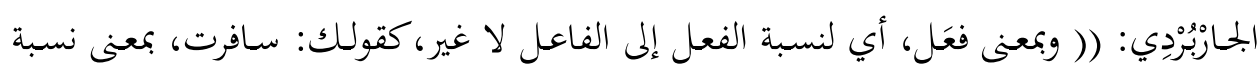
السفر إلى المسافر )( ) (6). وكذلك ما كان مسبوقاً بالسابقة "است" يقول ابن الحاجب: (( استفعل للسؤال غالباً:

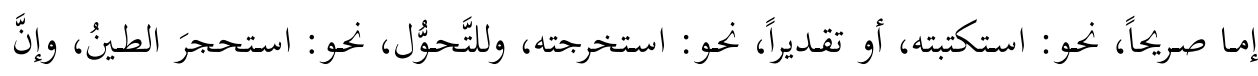

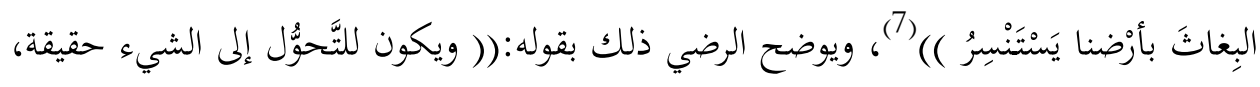

1- المصدر السابق 89،90/1، وينظر بحموعة الشافية من علمي الصرف والخط ص46/1.

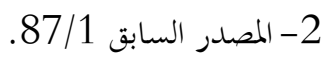

3- - شرح شافية ابن الحاجب للرضي

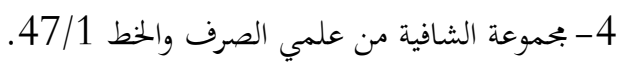

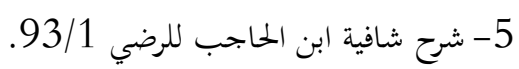

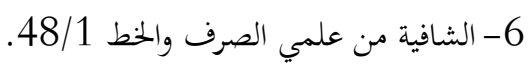

7- شرح شافية ابن الحاجب 110/1 الصرف والطط 
نهو: استحجر الطينُ: أي صار حجراً حقيقية، أو بحازاً، أي: صار كالحجر في الصلابة، وإن

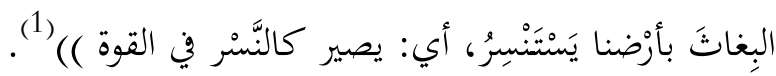
يتبيّن من هذه النصوص أن الباحث قد جانبه الصواب، ومرجععه قصر بحثه في مـا سمّاه العلماء أسباب التعدية أو وسائلها، ولو أنه رجع إلى نصوصهم عند حلديثهم عن معاني هذه النه

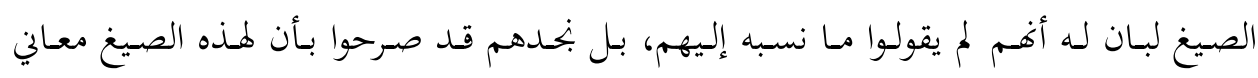

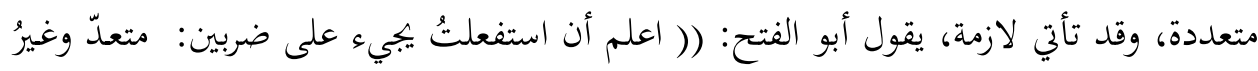

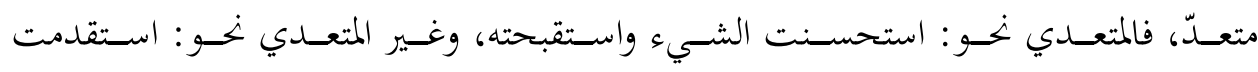

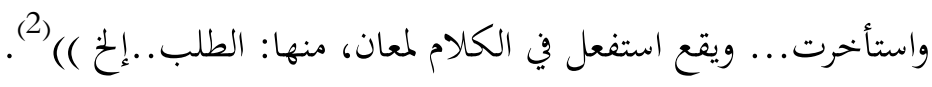
أريد أن أؤكد أن النحويين لم يعتمدوا المعيار الصيغي فحسب، بل المبل اعتمدوا المعيار الدلالي أيضاً، فالجملة التي رأسها الفعلي "ضرب" تنتقي مفعولاً خاصاً، والجملة التي رأسها الفعلي

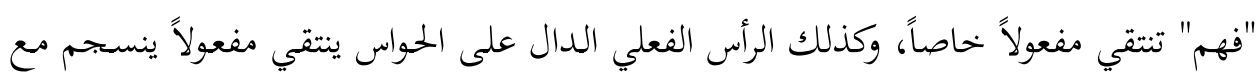

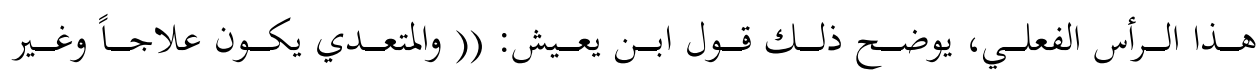

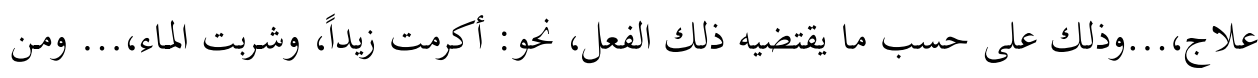

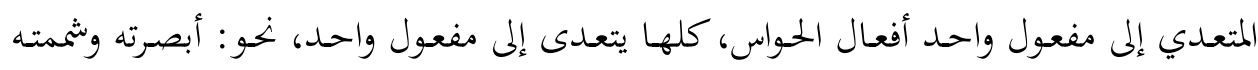

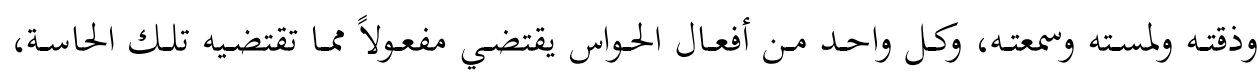

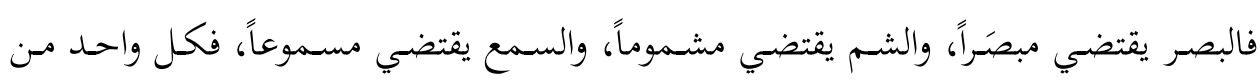

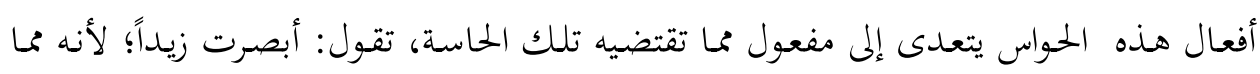

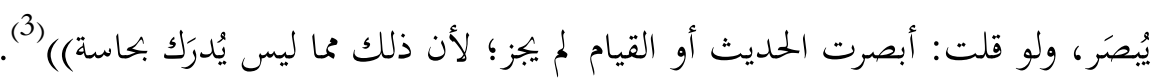

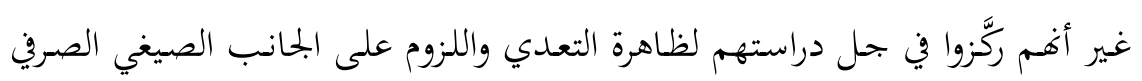
- كما سبق - والجانب التركيبي "القواعدي"، أي من حيث عدد الموضوعات التي يقتضيها الرأس

1- المصدر السابق ص111/1، وينظر بحموعة الشافية من علمي الصرف والخط 52/1.

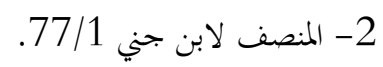
3- شرح المفصل 62/7. 
الفعلي، أي أن (( التعدي إضافة موضوع إلى الفعل، أو الزيادة في عدد الموضوعات، بمعنى إذا

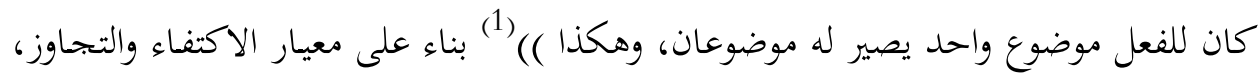
الذي ترتب عليه التقسيم الثلاثي للتعدي، إلا أني سأركز في هذا البحث على الجانب الدلالي،

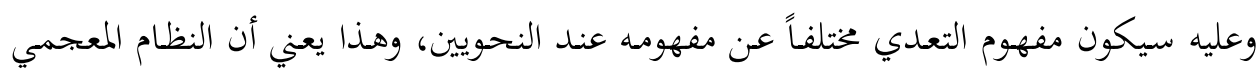

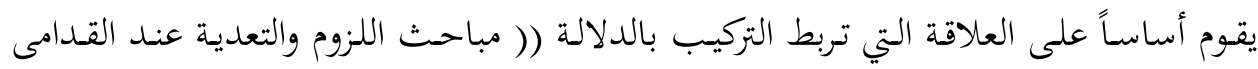

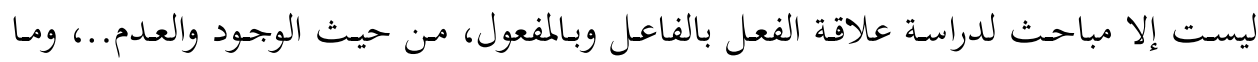

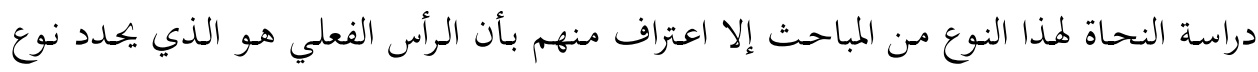

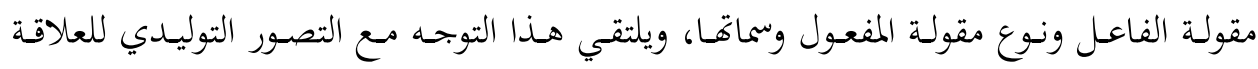

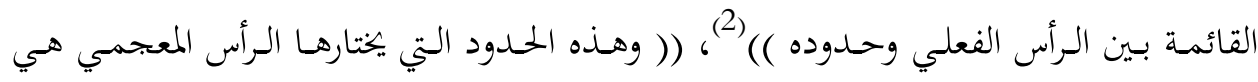

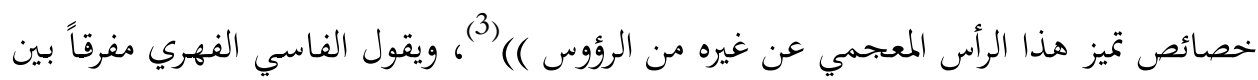

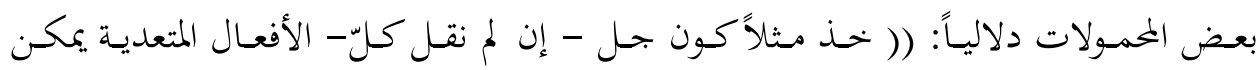

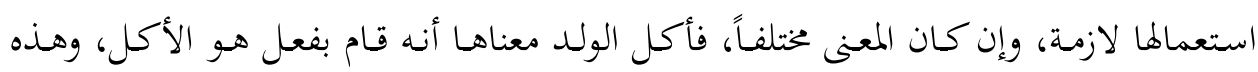

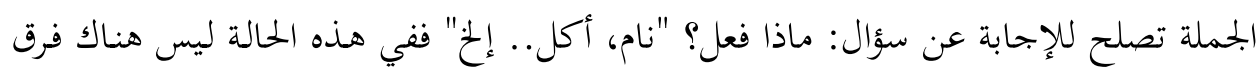
بين (أكل ونام). وأكل الولد التفاحة، ليس فعلاًا أو نشاطاً، وإنما هو إبحاز، بمعنى أن الأكل

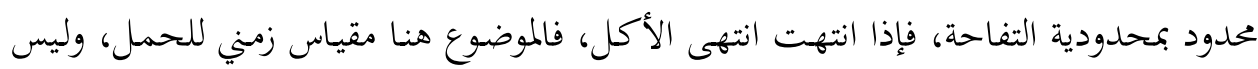
الأمر كذلك في أكل الولد..إلخ. فهناك دون شـك، أشياء كثيرة في التفريع المقولي يصرح . هـا

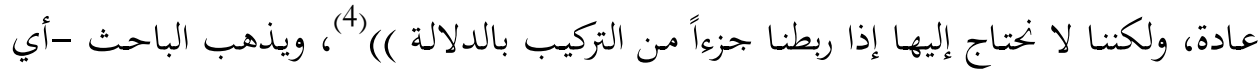

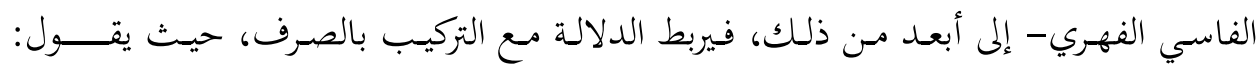

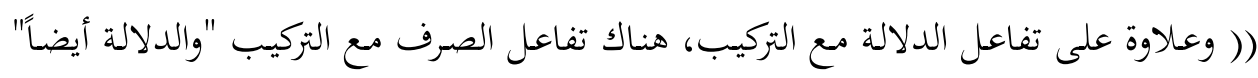

$$
\begin{aligned}
& \text { 1- المعجم العربي العصري وإشكالاته: أحمد بريسول، وكنزة بن عمر ص107. }
\end{aligned}
$$

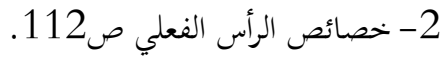

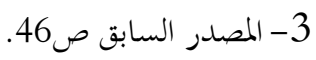

4- المعتم العربي المولد "إنشاء قاعدة معجمية عربية مولدة"، إشراف: عبد القادر الفاسي الفهري ص29،30.20. 
فلواصق الانعكاس والتفاعل والبناء للمجهول، وغيرها بتعل الدخلة التركيبية التقليدية غير لائقة، كما أن تعدد الدخلات التركيبية لنفس الفعل بعيد أن يكون هو الحل الأمثل )) (1). وقد طور الفاسي الفهري هذه المباحث في باب منفصل بعنوان: "التعدية ومسائل متصلة بها" في مؤلفه الشهير: "المعجم العربي، نماذج تحليلية جديدة" الذي تنـاول فيه كثيراً مـ قضايا التعدية، أقف على بعض منها في هذا المبحـث، مسترشداً بأفكاره التي حوّهـا إلى قواعد لسانية صـارت مرجعـاً لكتير مـن البحّاث اللسـانيين عنـد دراستهم لمسـائل ترتبط بالتركيسب والدلالـة والصرف، على الرغم من أن نظرية النحو التوليدي- كما هو معروف- لم تعتمد الدلالة في بداية مراحلها، محاولاً الربط بـين أفكار اللسـانيين التي فتحـت -بحق - البـاب على مصراعيه لإعـادة الدراسات اللغوية إلى طريقها الذي حادت عنه، بسبب إثارة اللسانيين لكثير من الإشكالات التي سأحاول الإجابة عنها في هذا البحثث المتواضع - وبين مـا اعتمده القـامى مـن النحويين، وصار يردده الكثير، وكأنه شيء مقدس يمنع الاقتراب منه، أو محاولة إعادة فهمه في قوالب جديدة، على الرغم من اقتناعنا التام بالمهود والقواعد التي وضعوها في ظل غياب ما أتيح لنا اليوم من وسائل الولوج إلى المعلومة بكل سهولة ويسر، لو أتيح لهم بعضٌ منها لكان هناك الكثير مما ينبغي حذفه، وإعادة النظر فيه مـ زوايـا قد تضع الحلول لكثير من الأسئلة التي نروم الإجابة عنها، للرفع من مستوى لغتنـا التي صـارت تعاني الكثير مـن العزوف بسبب هـذا الخلطط في كثرة القواعـد، ولعل الجانب الصرفي الصيغي - كما يقول اللسانيون- يعيد إلى لغتنـا شأفها إذا أجدانا حسن التعامل معه، لأنه السبيل الوحيد- حسب اطلاعي المتواضع - إلى التنميط والسبك والتعريب والإدخـال الذي صار مطلباً ملحاً في كثير من اللغات الحية اليوم كما في الإنحليزية.

1- المعجم العربي المولد "إنشاء قاعدة معجمية عربية مولدة" ص303، وينظر سمات الفعل وطرق بنائها

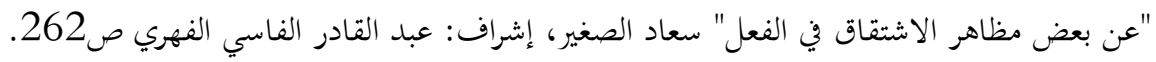


وقد لاحظ الفاسي الفهري(1) ذلك -أي ارتباط الدلالة بالتركيب والصرف- وضبط هذا النوع من التعدية من حيث الوضعية الدلالية للمفعول به، فصنّف التعدية في هذا الصدد إلى صنفين: تعدية إلى المكان، وتعدية إلى الأداة.

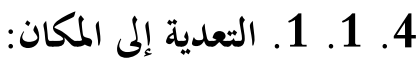

وقد مثل لهذا الصنف، بأمثلة، منها: بلغت الدار، صعدت المنبر. فالرأس المقولي في الجملتين يوزع محلين: "الفاعل+مفعول"، والرأس المعجمي ينتقي في

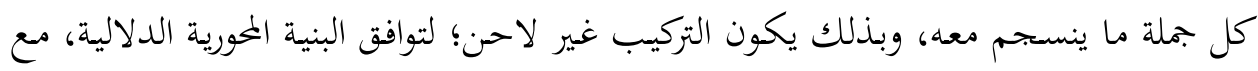

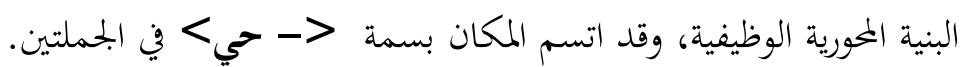

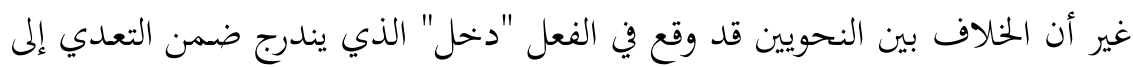

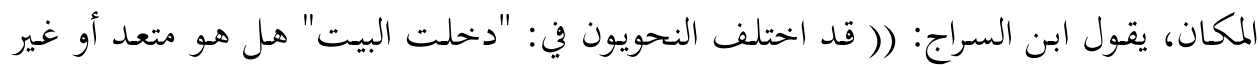

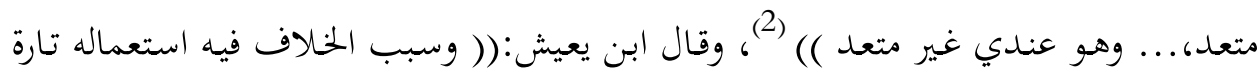

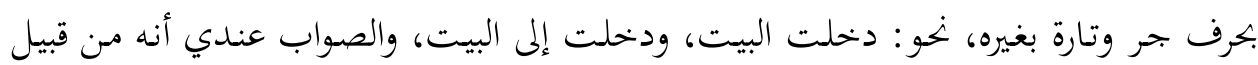

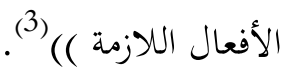

وقد اعتمد النحويون في هذا الحهم على أدلة، وهي:

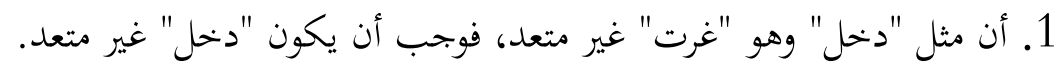

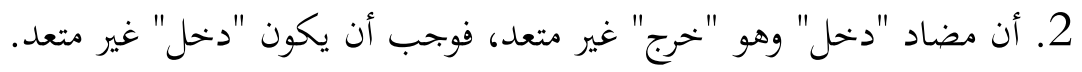

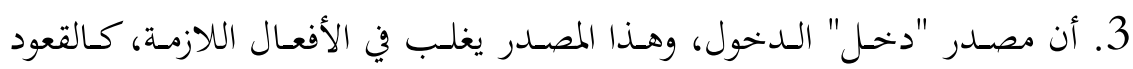
والحلوس. فالدليالان الأول والثاني يوضحهما قول ابن السراج: (( ودخلت مثل غرتُ، إذا أتيت الغور، فإن وجب أن يكون "دخلت" متعدياً وجبَ أن يتعدى "غرتُ" ودليهٌ آخر : أنك لا ترى لوى فعلاً من الأفعال يكون متعدياً إلا كان مضاده متعدياً، وإن كان غير متعد كان مضادُهُ غير

1 - 1 ينظر المعجم العربي، عبد القادر الفاسي ص138.

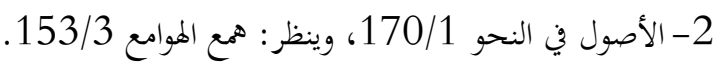
3- شرح المفصل 63/7. 
متعد، فَمن ذلك: تحركَ وسكنَ، فتحرك غير متعد وسكنَ غير متعد، وابيضَّ واسودَّ كلاهما غير متعد، وخرج ضد دخل، وخرج غير متعد، فواجب أن يكون دخل غير متعد () (1). والدليل الثالث يوضحه قول ابن يعيش:(( والذي يدل على ذلك [ أي: عدّ دخل

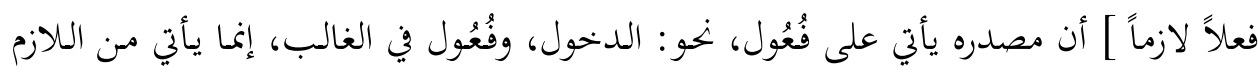
نحو القعود والجلوس () (2) وقــ فنّـد الفاسـي الفهـري هـذه الحجـج بسـرد بعض الأمثلـة، فحجـة النظير يفنـدها

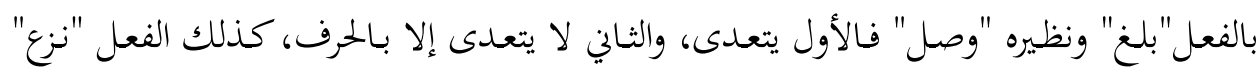
يساوي "سلب" و "انتزع" يساوي "استلب" إلا أن "سلب واستلب" يتعـدى إلى مفعولين و "نزع وانتزع" يتعديان إلى المفعول الثاني بالحرف، تقول: سلبه ماله، سلب ماله منه، نزعه ماله،نزع ماله منه (3)

وحجة الضد فنّدها بالفعل "منح" الذي ضده أو نقيضه الفعل "أحذّ" فالأول يتعدى إلى الثاني، أما "أحذ" فلا يتعدى إلى الثاني إلا بالحرف، تقول: منحت الرجل الكتاب، وتقول:

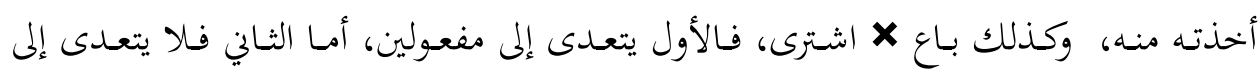
المفعول الثـاني إلا بـالحرف، تقول: بعته الكتـاب، اشتريت الكتـاب منـه، ولا تقول: * * اشتريته

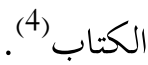
وكذلك فنّد الفاسي الحجة الثالثة بذكره بعض الأمثلة التي مصادرها على زنة "فُعُول" ومع ذلك جاءت أفعالها متعدية، لا لازمة، مثل: ركب، وعلا، وصعد، نقول: ركب فلان الدابة، وعلا الجبلَ، وصعد المنبرَ(5).

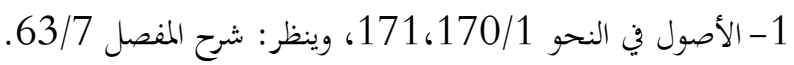
2- 2 شرح المفصل 63/7.

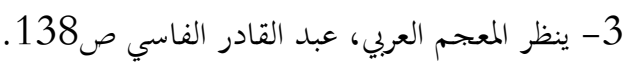

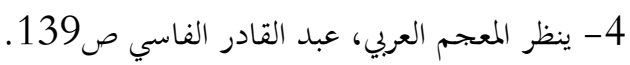
5- ينظر المصدر السابق ص140. 


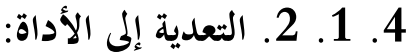

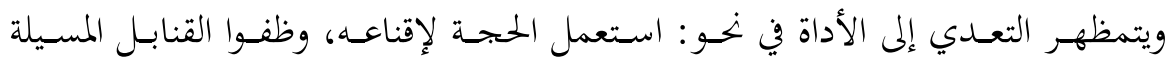
للدموع، فاقتضى الرأس الفعلي مُنفِّذاً وأداة "الحجة، القنابل"، وقد يقتضي الرأس الفعلي أداة

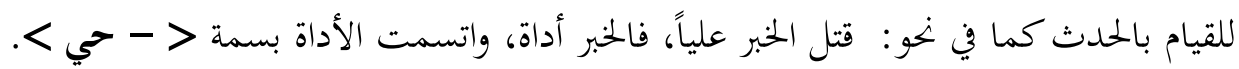

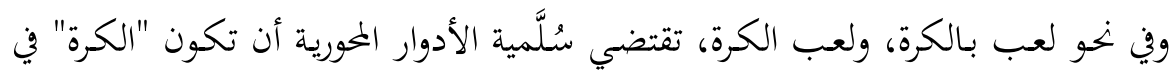

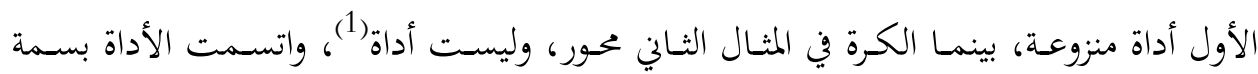

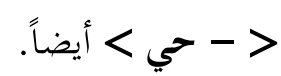

كما بخد أن الرأس المقولي يوزع محلين: "الفاعل+مفعول"، وأن الرأس المعجمي ينتقي

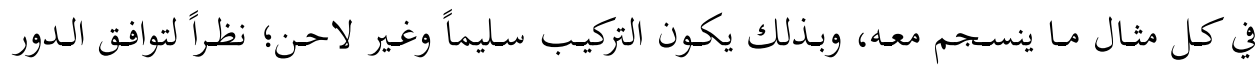

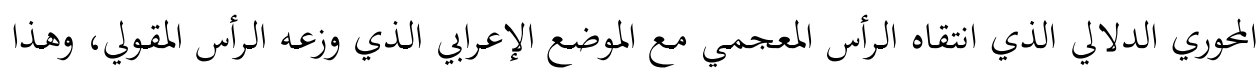

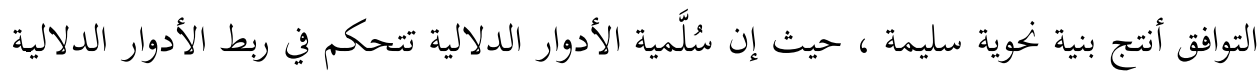

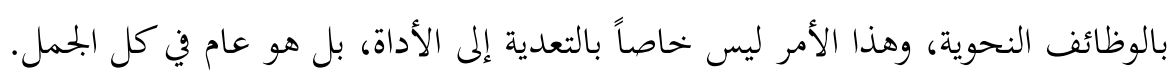

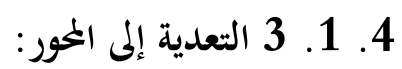

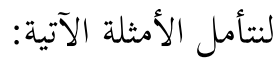

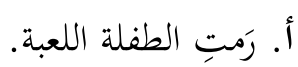

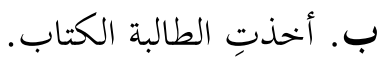

$$
\text { ج. د. أعطيتُ علياً الثوب. }
$$

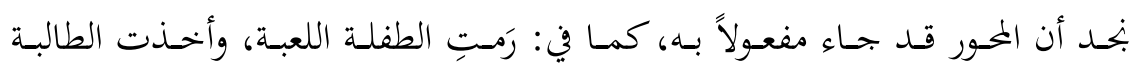
الكتـاب، فــالرأس الفعلـي يطلـب حسـين، الأول: القـائم بالحــدث أو المنفــذ، واتســم بسـمة >+حي>> والحد الثاني: المحور، واتسم المحور بسمة >-حي>

1- 1 ينظر المصدر السابق ص145، وخصائص الرأس الفعلي ص22. 
كما بجد أن المحور جاء مفعولاً ثانياً في: أعطيت زيداً الثوب، وأبلغته الخبر، واتسم المحور

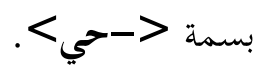

كمـا بحـد أن التوافق قـد تحقق بين الدور المحوري الدلالي الذي انتقـاه الرأس المعجمي، والموضع الإعرابي الذي وزعه الرأس المقولي في الأمثلة كلها.

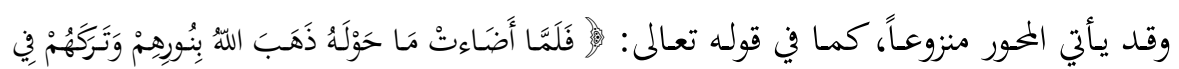

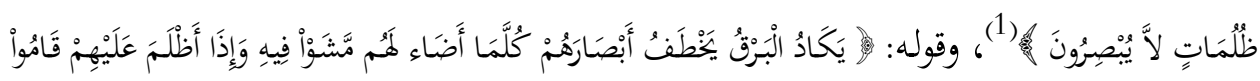

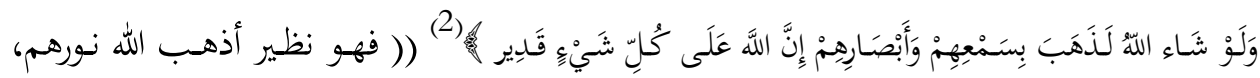

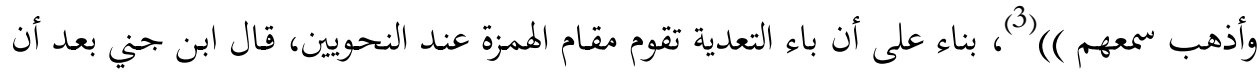

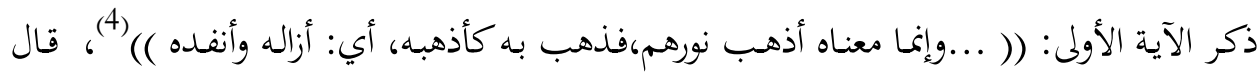

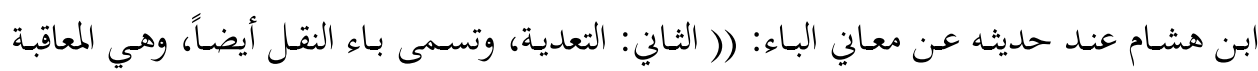

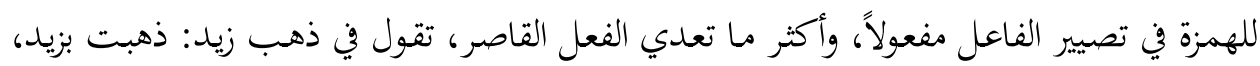

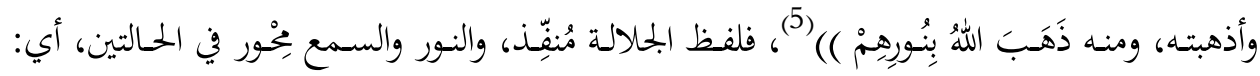

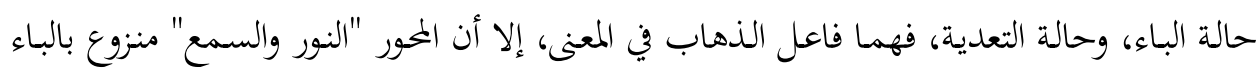

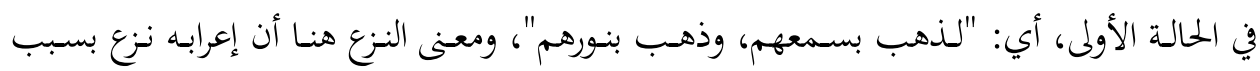
دخول حرف الجر عليه، فصار بحروراً بعد أن كان منصوباً، والمحور مربوط إلى الحمل نهوياً في الحالة ودمثي الثانية "أذهب الله نورهم، أذهب الله سمعهم"، أي أنه مفعول به منصوب للفعل، فالبنية المحورية لــ: ذهب الله بنورهم، وأذهب الله نورهم: أ. [ ذهب م محور> منف

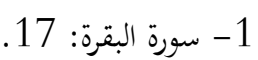

$$
\begin{aligned}
& \text { 2- 2- سورة البقرة: } 20 . \\
& \text { 3- المعجم العربي، عبد القادر الفاسي صدرة } 142 . \\
& \text { 4- المتسب 214/2. } \\
& \text { 5- المغني ص138، 811، وينظر همع الهوامع 114/4، 13/5، وحاشية الصبّان 126/2. }
\end{aligned}
$$




$$
\text { ب. [ > ذهب محور > منفذ }
$$

كما ذكر النحاة أن الفعل المتعدي إلى مفعولين يجيجوز فيه الاقتصار على المفعول الأول

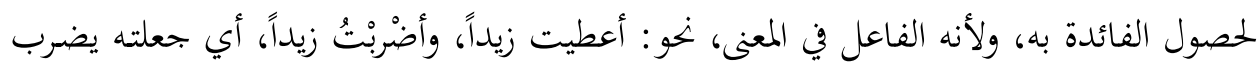
غيره

4. 1. 1. 4. 4. التعدي إلى المدف:

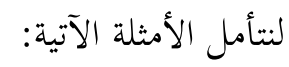

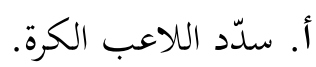

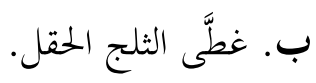

ج. دخل الدخان الغرفة.

د. كسوت الفقير جبّة.

هـ أعطى الوالد ابنه مالاً.

بحد أن الرأس المقولي يوزع محلين: "الفاعل+مفعول" في: سدّد اللاعب الكرة، غطى الثلج

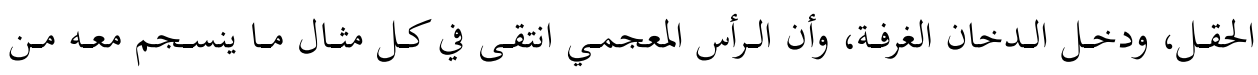

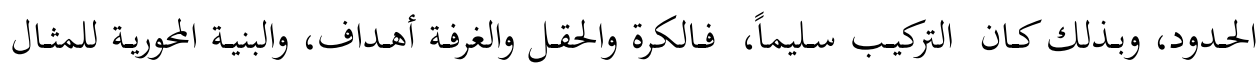

$$
\begin{aligned}
& \text { [ سدّد ( قائم بالحدث/ مُنبِّذ، ضحية/ هدف ) ] } \\
& \text { بينما البنية المحورية للمثال الثاني: }
\end{aligned}
$$

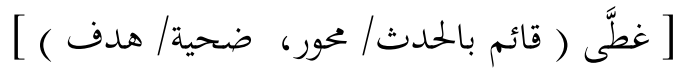

$$
\begin{aligned}
& \text { والبنية المحورية للمثال الثالث: } \\
& \text { [ دخل ( قائم بالحدث/ محور، هدف ) ] ل }
\end{aligned}
$$

1- ينظر المعجم العربي، عبد القادر الفاسي ص142.

$$
\text { 2- ينظر الأصول في النحو 177/1. ينطرئ عبد الفادر الفاسي }
$$


وقد لاحظ الفاسي الفهري أن المفعول الأول في "أعطى وكسا ومنح" يكون هدفاًً)، ويدخل ضمن الهدف "المعاني، والمستفيد أو المتلقي"، وهذه الأفعال مؤثرة، أي: أهـا تنفذ مـن الفاعل إلى المفعول، وتؤثر فيه، ولابد أن يكون المفعول الأول فاعلاً بالثاني، قال ابن يعيش: () وأما ما يتعدى إلى مفعولين، فهو على ضربين، أحدهما ما يتعدى إلى مفعولين، ويكون المفعول الأول منهما غير الثاني، والآخر : أن يتعدى إلى مفعولين، ويكون الثاني هو الأول في المعنى، فأما الضرب الأول فهي أفعال مؤثرة تنفذ من الفاعل إلى المفعول وتؤثر فيه، نحو قولك: أعطى زيد

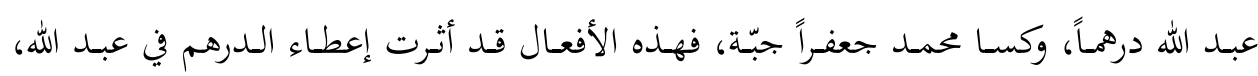
وكسوة الجبـة في جعفـر، ولابـد أن يكون المفعول الأول فـاعلاً بالثاني، ألا ترى أنك إذا قلت: أعطيت زيداً درهاً، فزيدٌ فاعل في المعنى؛ لأنه آخذ الدرهم، وكذلك كسوت زيداً جبّة، فزيدٌ هو

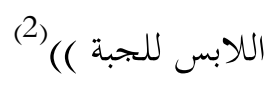

$$
\begin{aligned}
& \text { والبنية المحورية للجملتين: كسوت الفقير جبّة، أعطى الوالد ابنه مالاً. } \\
& \text { [ أعطى ( قائم بالحدث/ منفذ، هدف، محور ) }
\end{aligned}
$$

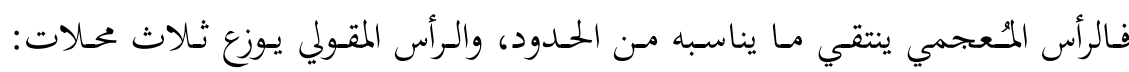
"الفاعل +مفعول1+ مفعـول2 "، وبـلك حـدث التوافق والانسجام بين البنية المحوريـة الدلالية

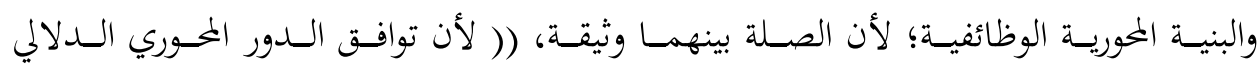

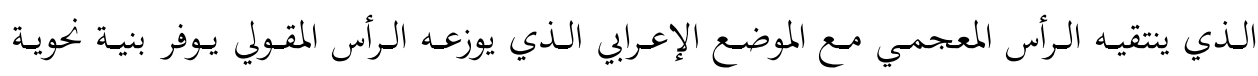

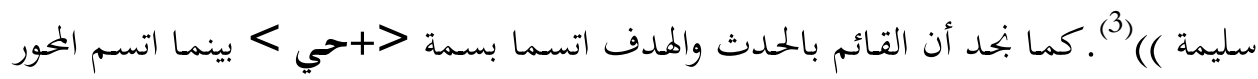

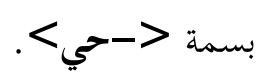

1 - ينظر المعجم العربي، عبد القادر الفاسي ص148.

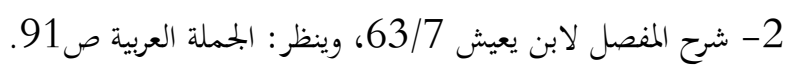

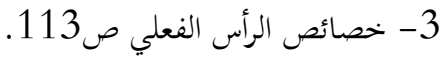




\section{1. التعدي إلى أكثر من مفعول:}

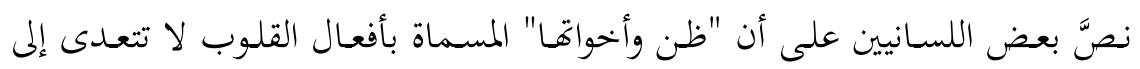

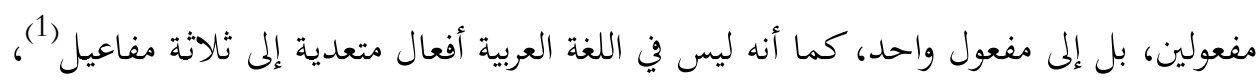

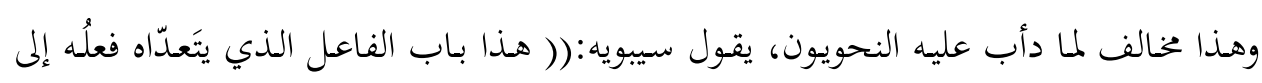

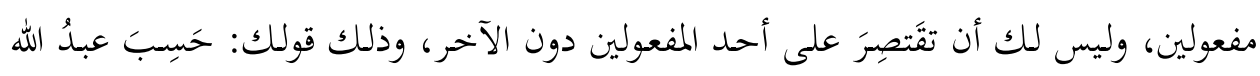

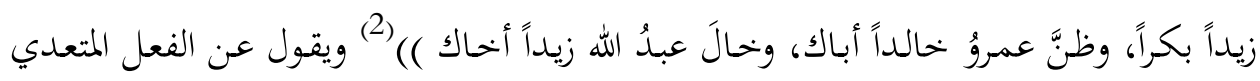

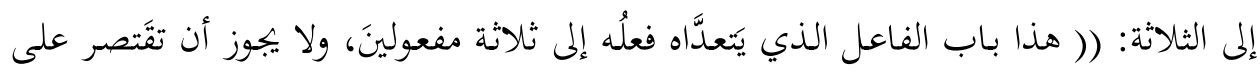
مفعول منهم واحدٍ دون الثلاثة؛ لأنّ المفعول ههنا كالفاعل في الباب الأوَّل الذي قبله في المعنى، لئل

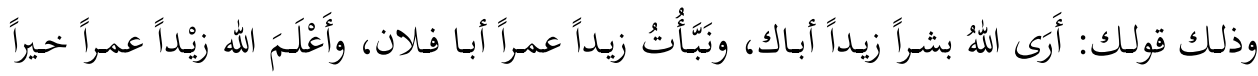

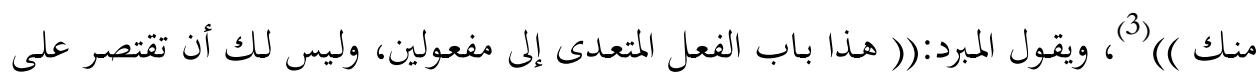

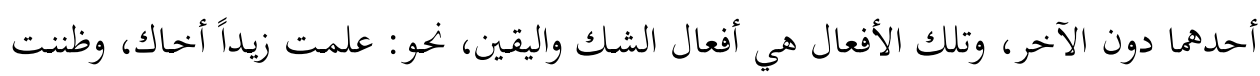

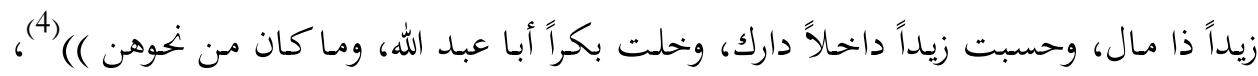

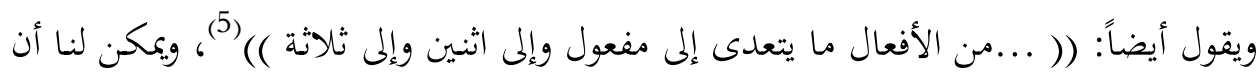
نستعرض هذا الحكم في الصنفين المذكورين.

\section{1. 2. 2 2. التعدي إلى مفعولين (ظن وأخواتما):}

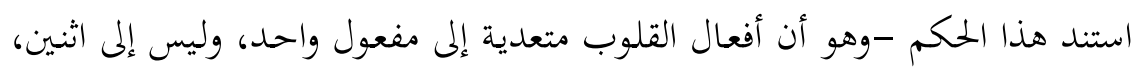

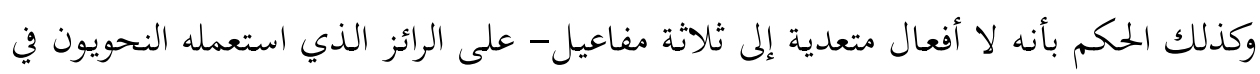

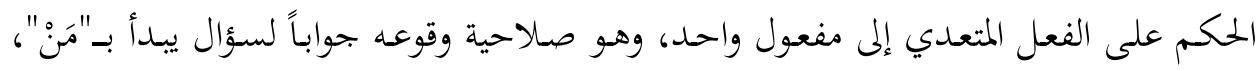

$$
\text { 1- ينظر الجملة العربية ص191- 91- } 94 .
$$

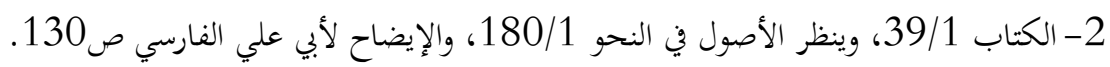

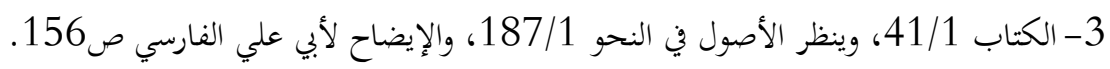

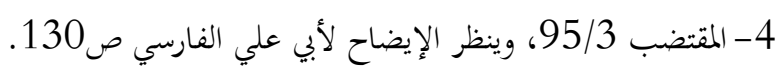

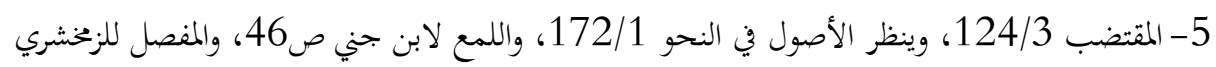


يقول ابن يعيش: (( والتعدي: التجاوز، يقال: عدا طوره، أي: بتحاوز حده، أي أن الفعل بتحاوز

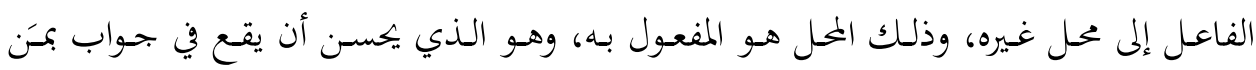

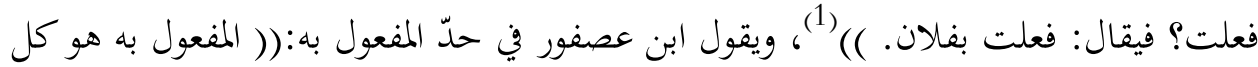

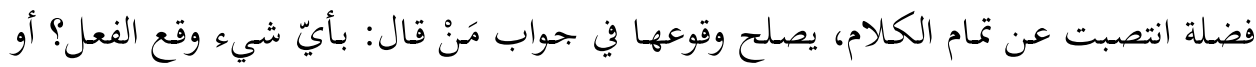

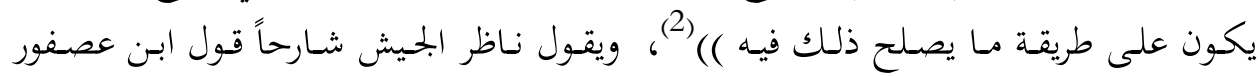

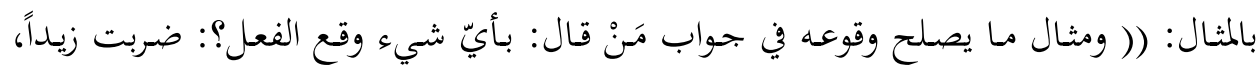

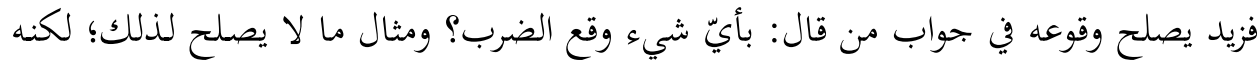

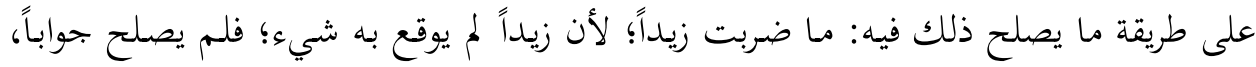
لكنه على طريقة ما يصلح ذلك فيه () (3). يتضـح مـن هـذه النصـوص أن المفعـول بـه لابـد أن يكـون صـالحاً للجـواب عـن هـــا السؤال، وبناء على هذا الأمر المفصلي يمكننا إخضاع بعض الجمل لروائز تحديد المفاعيل، وهي

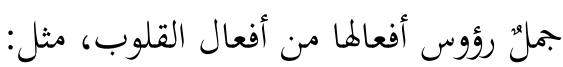
1. "ظن، خال، حسب، رأى" زيد خالداً قائماً. حيث المفعول الأول ينسجم مع رائز الاستفهام ويستجيب له: 1. أ. مَنْ "ظن،خال، حسب، رأى" زيد قائماًٌ والجواب: "خالداً". بينما لا يمكن أن يستجيب المفعول الثاني لهذا الرائز، وتكون الجملة لاحنة:

$$
\text { 1. ب. *"مَّن، ماذا" "ظن، خال، حسب، رأى" زيد خالداً؟ }
$$

(وهذا دليل قاطع على أن العنصر "قائماً" لا يمكن أن يكون مفعولاً ثانياً، ولا ينبغي الانخداع بالوسم الإعرابي الذي يحمله هذا العنصر))(4).

1- شرح المفصل، لابن يعيش 62/7، وينظر الأصول في النحو 171/1، التخمير في شرح المفصل 319/1.

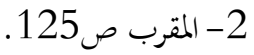

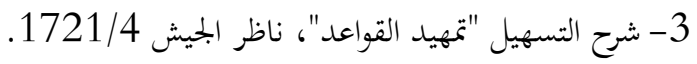
4- الجملة العربية ص92. 
وهذا الرأي ذكره الرضي، حيث نصَّ على أن هذه الأفعال متعدية إلى مفعول به، لا إلى مفعولين، يوضح ذلك قوله: (( وأفعال القلوب في الحقيقة لا تتعدّى إلا إلى مفعول واحد، وهو

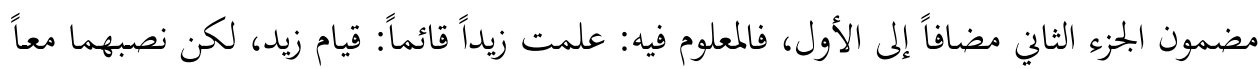

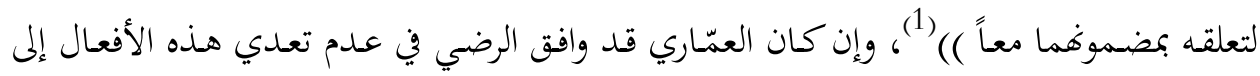

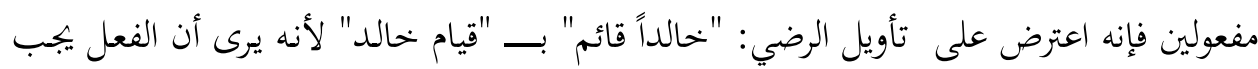
أن يقع على "خالد قائم" وليس على "قيام خالد" حيث يقول: (( وكان الأسترباذي من النحاة القلائل الذين تنبهوا إلى هذه المسألة، فقد لاحظ أن هذه الأفعال متعدية في الحقيقة إلى مفعول بـ الهـ

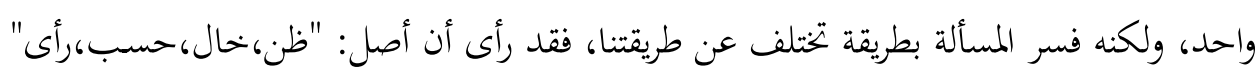

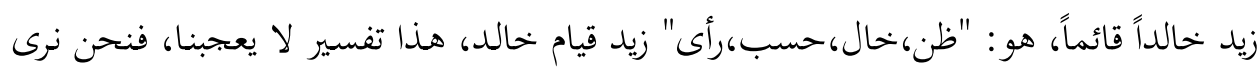

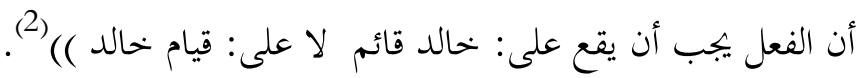

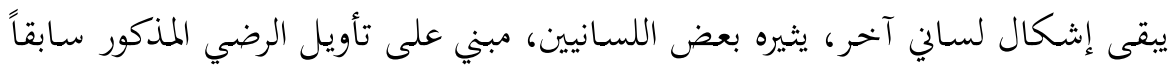

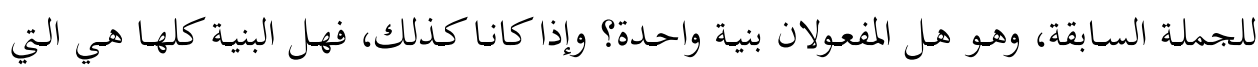
تأخذ الدور أو لا؟ وهذا الإشكال يندرج في إشكال آخر عام، وهو: هل الدور الدلالي الواحد يربط إلى الوظيفة الإعرابية الواحدة(3).

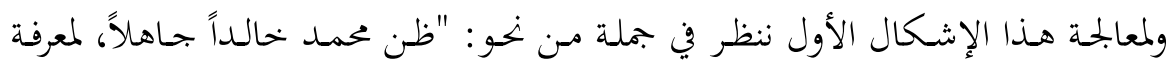

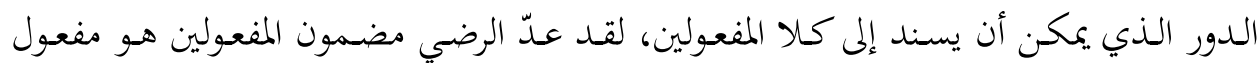

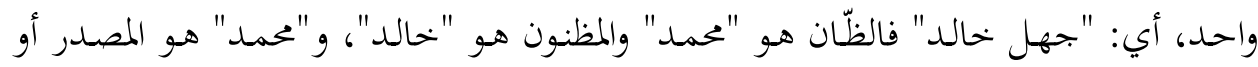
القائم بالحدث، و"خالد" هو الهدف؛ لأنه المقصود بالظن، أو هو موضوع الظن، و "جاهلا" هو هو هو هو

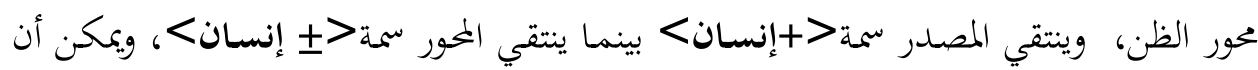
نمثل لهذا النوع من الأفعال بالشكل الآتي:

$$
\begin{aligned}
& \text { 1 - شرح الرضي 301/1. } \\
& \text { 2- الجملة العربية ص93. } \\
& \text { 3- ينظر خصائص الرأس الفعلي ص230، 233، } 233 .
\end{aligned}
$$




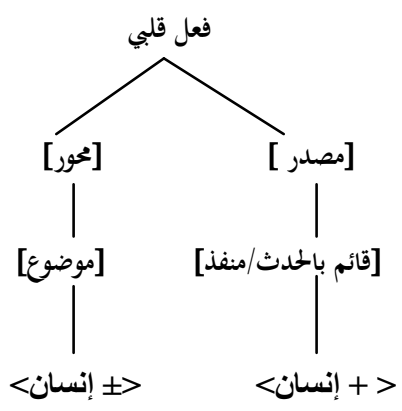

يتبين من الترسيمة إمكانية ارتباط الدور المحوري الدلالي الواحد (المحور)في هذا الصنف من الأفعال بوظيفتين إعرابيتين: "مفعول 1+ مفعول 2"؛ لافتقار هذا الصنف للمفعولين، وإمكانية تفرع دورين محوريين دلاليين (محور/ هدف) عن الدور المحوري الدلالي الواحد (المحور) الذي يقوم

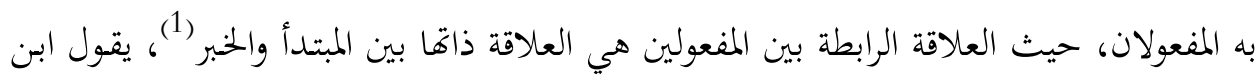

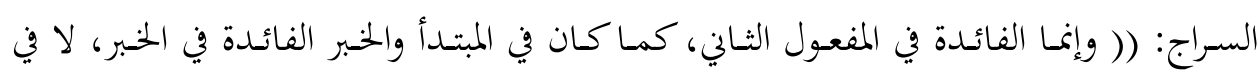

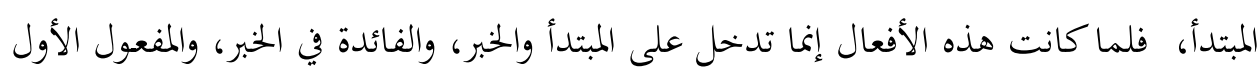

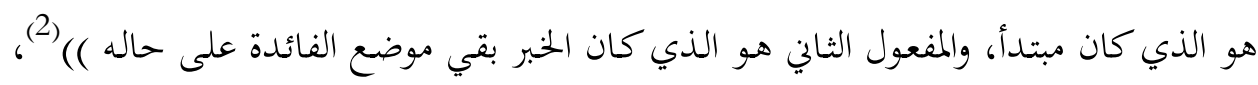

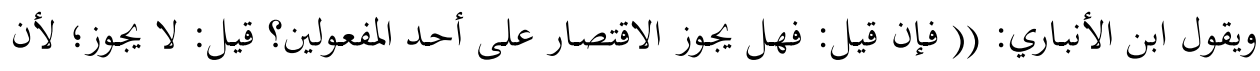

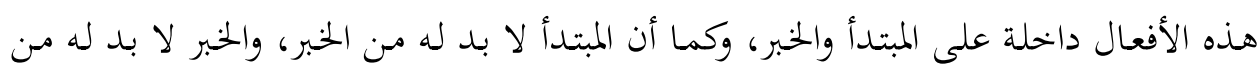
المبتدأ، فكذلك لا بد لأحد المفعولين من الآخر )( (3).

\section{1. 3. 3. 1التعدي إلى ثلاثة مفاعيل:}

ذكرت في الجزئية السابقة أن بعض اللسانيين أنكر وجود أفعال متعدية إلى ثلاثة مفاعيل، وأضيف هنا أنه قد عدّ هذه الأفعال منقولة، يقول العمّاري: (( وما يثير الانتباه أهم - ليقصد

$$
\begin{aligned}
& \text { 1- ينظر خصائص الرأس الفعلي ص231-233. }
\end{aligned}
$$

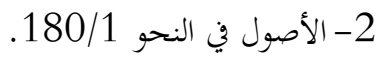

3- أسرار العربية صالاصول ف160، وينظر كتاب المقتصد 189/1، 499، واللمع لابن جني ص46، واللباب للعكبري 247/1 
النحويين- لم يعثروا لهذا النوع من الأفعال ما يوازيه من الأفعال العادية، وقد اعتذروا عن ذلك بأن لاحظوا أن "أعلم" وأخواته منقولة عن "علم" وأخواته () (1).

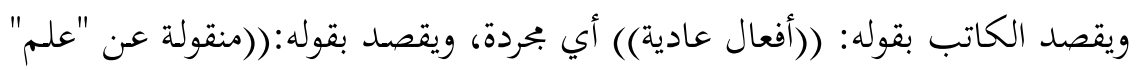

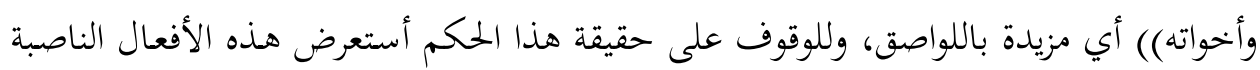
لثلاثة مفاعيل، وهي كما ذكرها النحاة:

$$
\begin{aligned}
& \text { علم ٪ أعلم. } \\
& \text { نبأ ـ أنبأ أو ـ } \\
& \text { خبر } \\
& \text { رأى } \\
& \text { حدث ـ حدّث }
\end{aligned}
$$

هذه أفعال كلها اتصلت بها اللواصق، وبسببها صارت عاملة هذا العمل، أي نصـب ثلاثة مفاعيل، يقول أبو علي الفارسي: (( باب الفعل الذي يتعدّى إلى ثلاثة مفعولين، هذا الباب

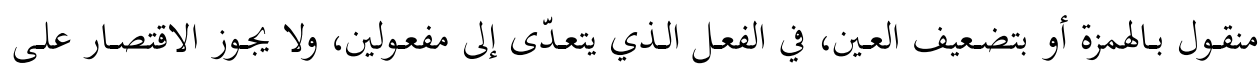

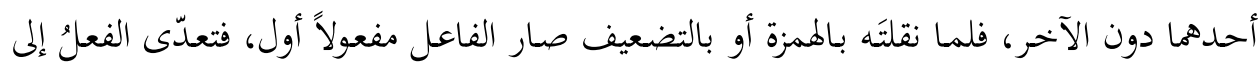

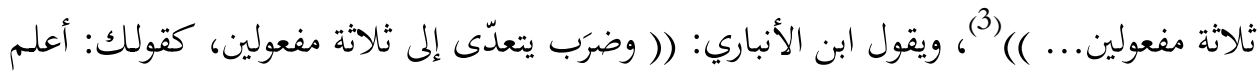

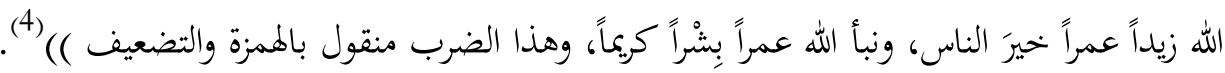

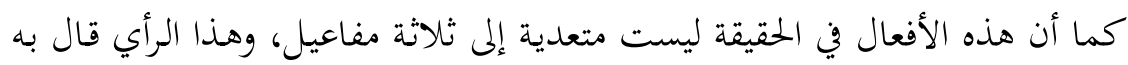

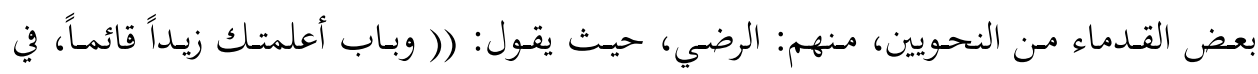

$$
\text { 1 - الجملة العربية ص93، } 94 .
$$

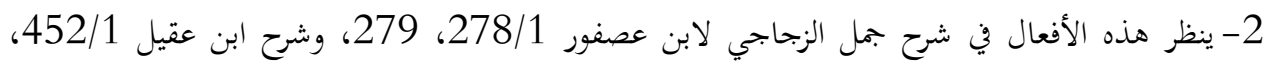

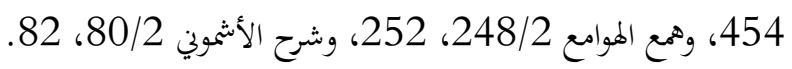

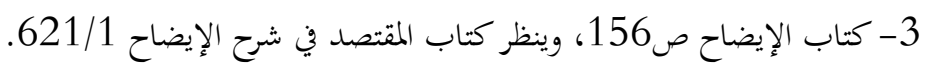

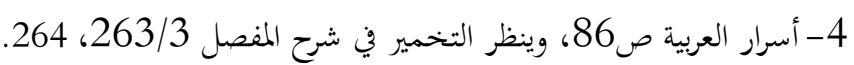


الحقيقة متعدٍ إلى مفعولين، فبإنّ "المُعَكم" هو المخاطب و "قيـام زيد" هـو المعلوم، كمـا قلنـا في

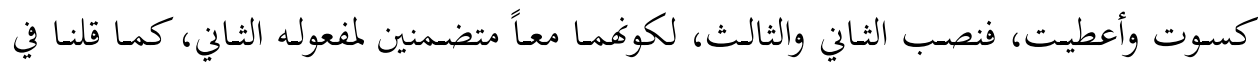
علمـت )) (1)، والسيوطي الذي يقول:(( وقيل يمتنع الاتساع مع المتعدي إلى اثنين أيضاً؛ لأنه

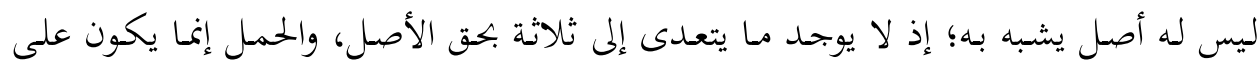

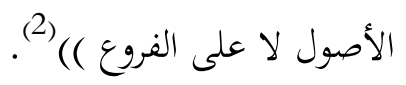

وقد أخضع الباحـث بعض الجمل التي رؤوس أفعالها مـن هـذه الأفعـال لروائز تحديد المفاعيل، بنـاء على النصوص التي نقلتها عن بعضهم في الفقرة السابقة، وتفيد أن المفعول بـه

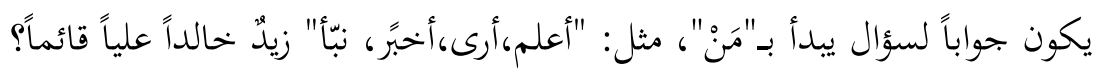
حيـث يمكـن لنـا أن نسـتفهم عـن المفعـول الأول، باسـتخدام رائـز الاسـتفهام: مَسنْ

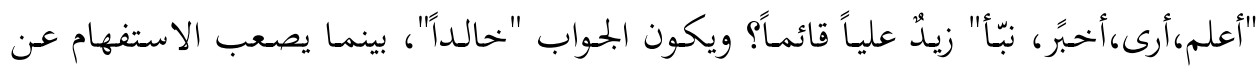

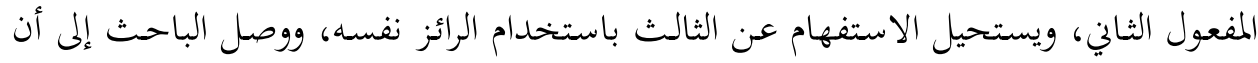

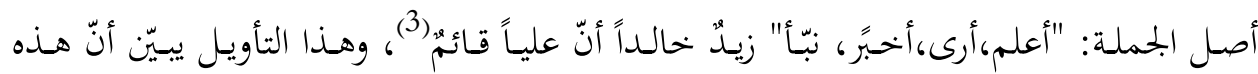

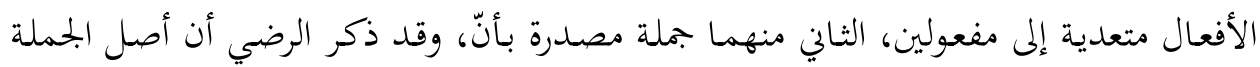

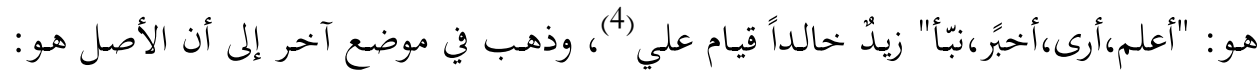

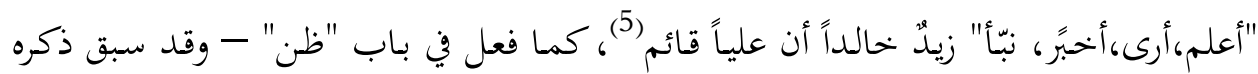
في الفقـرة السـابقة- وقــ رفض الباحثث التقـدير الأول؛ (( لأنه يُوقِع الفعـل على قيـام عليّ، والأصل أن يقع على: عليّ قائم )( ).

$$
\begin{aligned}
& \text { 1- شرح كافية ابن الحاجب للرضي 302/1. } \\
& \text { 2- همع الموامع 169/3. }
\end{aligned}
$$

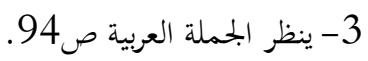

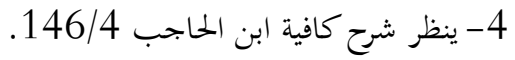

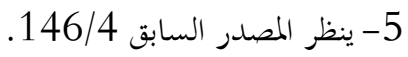

$$
\begin{aligned}
& \text { 6- الجملة العربية ص95. }
\end{aligned}
$$




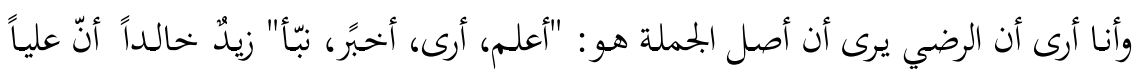

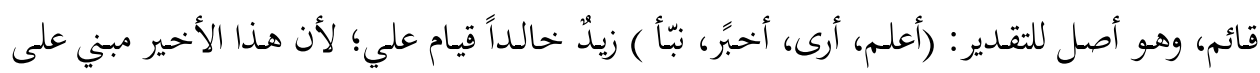
الأول؛ ذلك أن عملية السبك لابد أن تحتوي على (أن). يققى مشكل آخر يثيره بعض اللسانيين (1)، وهو المشكل نفسه الذي أنس ذكرته في الجزئية

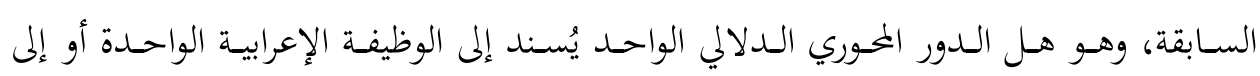

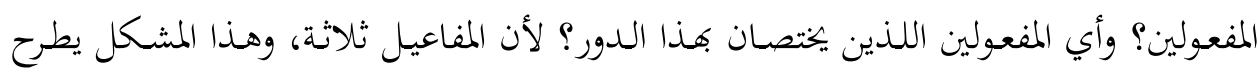

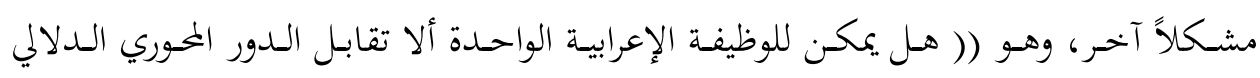
وبالعكس () (2)

هذا الصنف من الرؤوس الفعلية يطلب أربعة حدود موضوعات، يقوم الحد الأول بدور

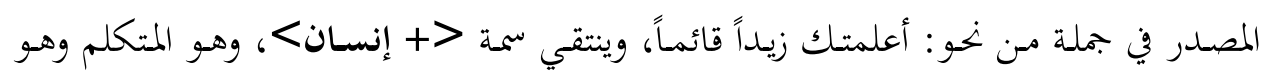

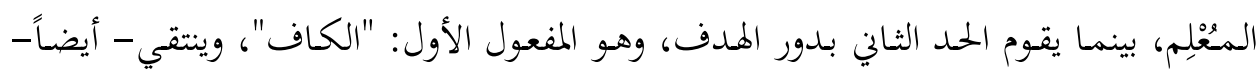

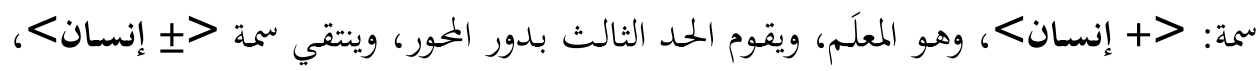
وهما المفعولان الثاني والثالث، وهو المعلوم، ويككن أن أمثل بالشكل الآتي:

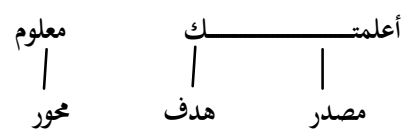

يتضح أنه لا فرق بين الرؤوس الفعلية المتعدية لمفعولين والرؤوس الفعلية المتعدية إلى هلى

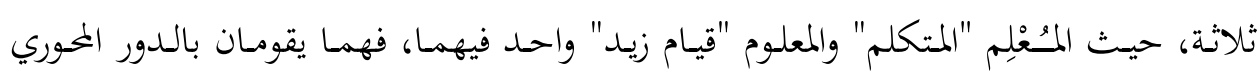

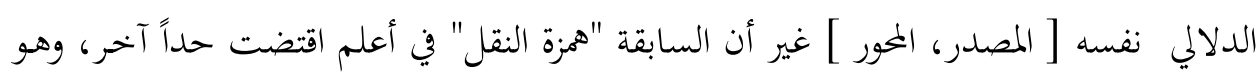
[ الهدف ] ويتأتى من هذا أنه يمكن ربط الدور المحوري الدلالي الواحد بأكثر من وظيفة إعرابية

$$
\text { 2- 1- ينظر خصائص الرأس الفعلي ص234. } 234 .
$$


بشرط تحقق الترابط المعنوي بين العنصرين اللذين يكونان مُكوِناً واحداً، وهذا الترابط متحقق في هذا النوع من الرؤوس الفعلية، فهما المبتدأ والخبر قبل دخول الرأس الفعلي (1). كما أريد أن أضيف أن هذا الصنف من الرؤوس المتعدية إلى ثلاثة مفاعيل -الذي

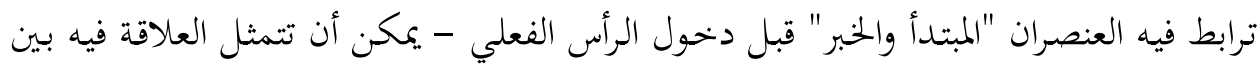

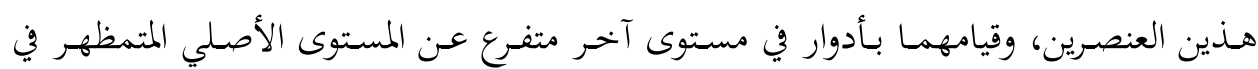
الترسيمة السابقة كما في الشكل الآتي (2):

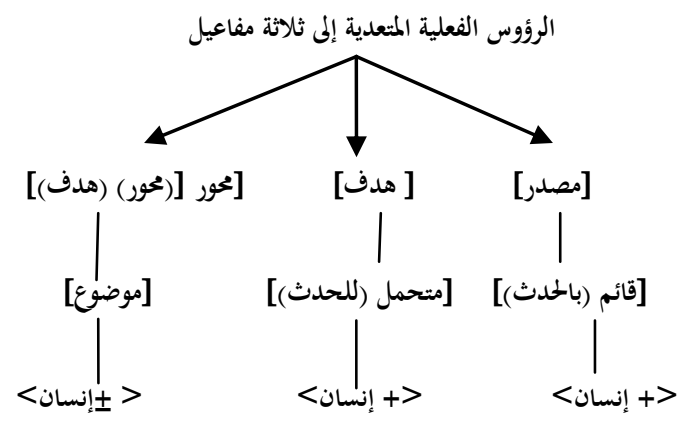

\section{نتائج البحث:}

أستطيع القول إنني بعد هذه الجحولة بين بعض الكتب النحوية والصرفية القديمة، وبعض

الكتب اللسانية الحديثة التي تناولت مسائل التعدية وصلت إلى النتائج الآتية:

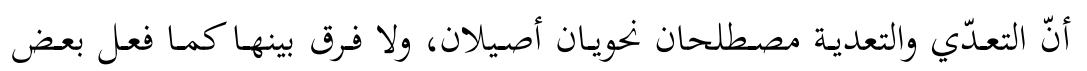
اللسانيين.

أنّ الفعل المتعدي واللازم يشتركان في التعدي، كمـا نصّ على ذلك بعض النحاة،

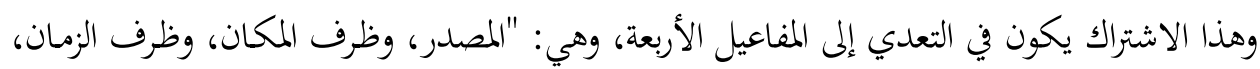
والحال".

$$
\text { 2- ينظر المصدر السابق ص236 ينط الرأس الفعلي ص235، } 236 .
$$


أنّ المعايير التي وضعها النحويون للتفريق بين المتعدي واللازم هي معايير قاصرة،

يجب إعادة النظر فيها ودراستها دراسة علمية خاضعة للروائز التي قال بها النحويون أنفسهم.

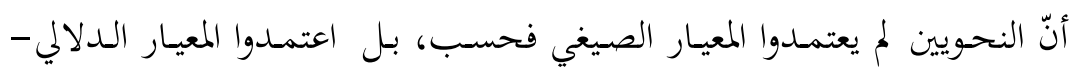

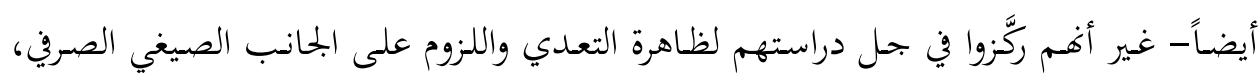
والجانب التركيبي "القواعدي" أي من حيث عدرو في دران الموضوعات التي يقتضيها الرأس الفعلي، بناء على معيار الاكتفاء والتجاوز، الذي ترتب عليه التقسيم الثلاثي للتعدي.

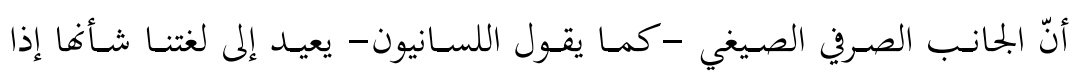

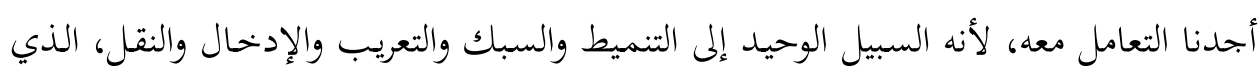
صار اليوم مطلباً ملحاً في كثير من اللغات الحية اليوم، كما في الإنحليزية.

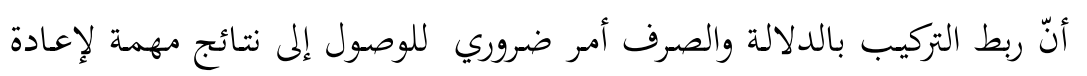

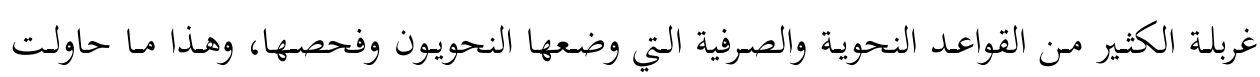
التركيز عليه، وبخاصة ربط الدلالة بالتركيب. أنّه ليس في لغتنا العربية أفعال متعدية إلى مفعولين، ولا أفعال متعدية إلى ثلاثة

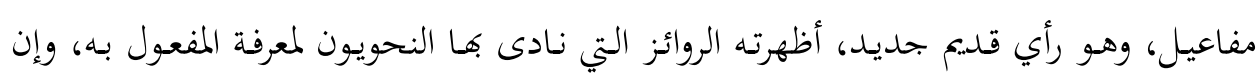

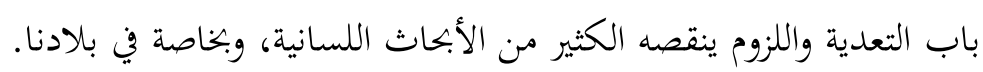

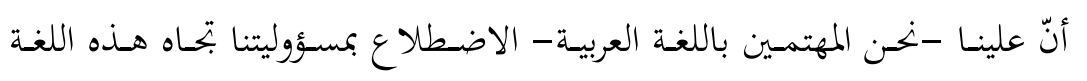
العظيمة، وذلك بالتواصل مع اللسانيين العرب -على الأقل - للوقوف على أبحاثهم اللسـانية المبتكرة، وأخذ المفيد والمناسب لفهمنا. 


\section{المصادر والمراجع}

القرآن الكريم، مصحف المدينة. 1- آليات توليد المصطلح، وبناء المعاجم اللسانية الثنائية والمتعددة اللغات، خالد اليعبودي،

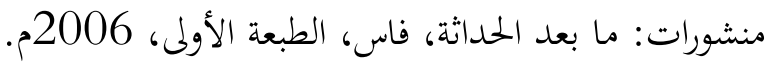

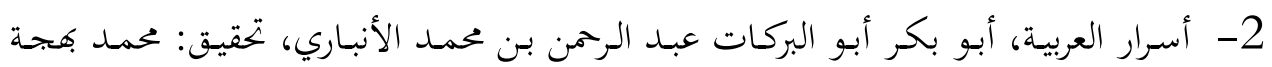

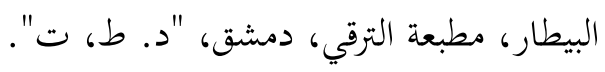

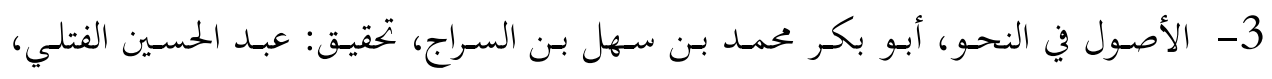

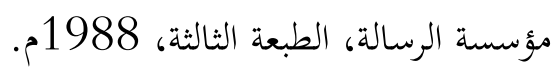

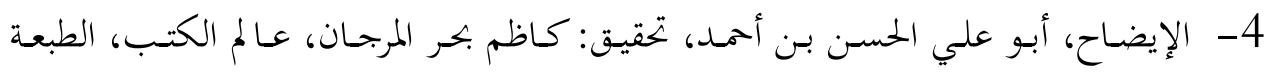

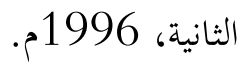
5- الجملة العربية "دراسة لسانية" عبد العزيز العماري، مطبعة آلفو - برانت، فاس، الطبعة الأولى، 2004م.

6- حاشية الخضـري على شرح ابن عقيل، ضـبط وتصحيح: يوسف البقاعي، دار الفكر،

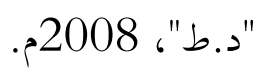

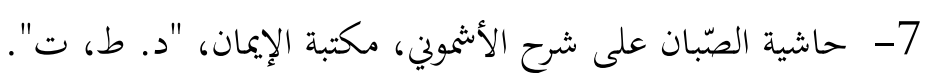

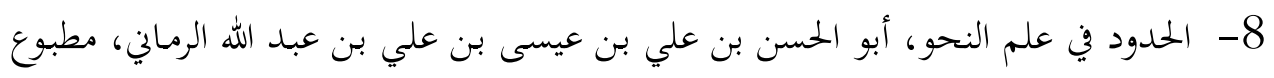

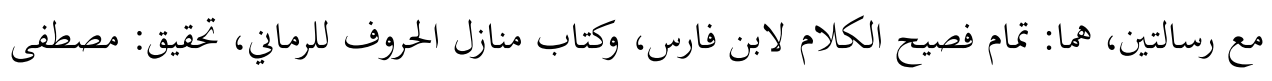

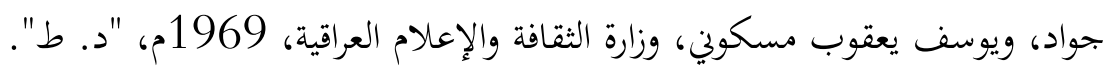
9- خصائص الرأس الفعلي وظواهر من انتظام المعجم، سرور اللحياني، منشورات: كلية الآداب ولاب

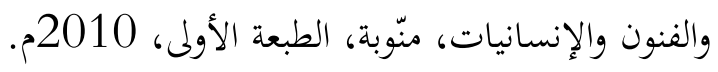

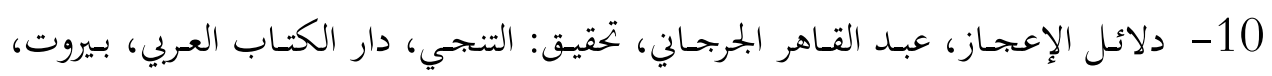
1415هـ، 1995م، "د. 195 
11- الزمن في اللغة العربية، بنياته التركيبية والدلالية، الحمد الملاخ،دار الأمان، الطبعة الأولى، 2009 12- سمات الفعل وطرق بنائها "عن بعض مظاهر الاشتقاق في الفعل" سعاد الصغير، إشراف: عبـد القـادر الفاسـي الفهري: منشـورات: معهـد الدراسـات والأبحـاث للتعريـب، الربـاط، مـايو 2004 13- شرح الأشموني، لألفية ابن مالك، تحقيق: عبد الحميد السيد عبد الحميد، المكتبة الأزهرية

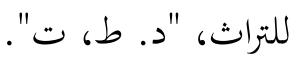
14- شـرح الأنموذج في النحو، جمـال الدين الأردبيلي، تحقيق: حسـني عبد الجليل يوسف،

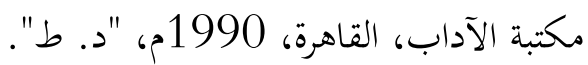
15- شرح ابن عقيل على ألفية ابن مالك، تحقيق: محمد محيي الدين عبد الحميد، "د.ط،تات". 16- شرح التسهيل، المسمى: تمهيد القواعد بشرح تسهيل الفوائد،ناظر الجيش، تحقيق: علي محمد فاخر، وآخرين، دار السلام، القاهرة، الطبعة الأولى،

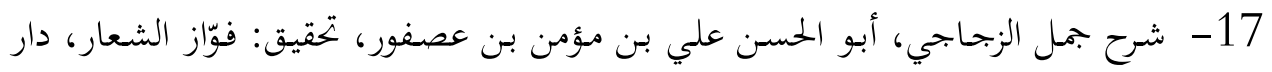

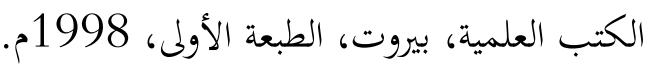
18- شرح شافية ابن الحاجب، رضي الدين محمد بن الحسن الأستراباذي، مع شرح شواهده لعبد القادر البغدادي، تحقيق: محمد نور الحسن ومحمد الزفراف، ومحمد محيي الدين عبد الحميد، رصني،

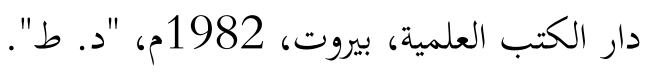
19- شرح كافية ابن الحاجب، رضي الدين محمد بن الحسن الأستراباذي، تحقيق: إميل بديع

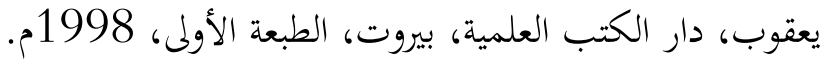

20- شرح المفصل في صنعة الإعراب الموسوم بالتخمير، القاسم بن الحسين الخوارزمي، تحقيق:

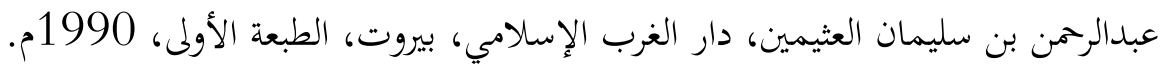

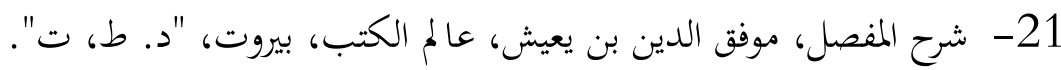


22- كتاب سيبويه، أبو بشر عمرو بن عثمان بن قنبر، تحقيق: عبد السلام محمد هارون، دار

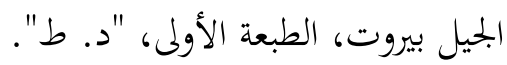
23- كتـاب المقتصـد في شـرح الإيضـاح عبـد القـاهر الجرجـاني، تحقيق: كـاظم بحـر المرجـان،

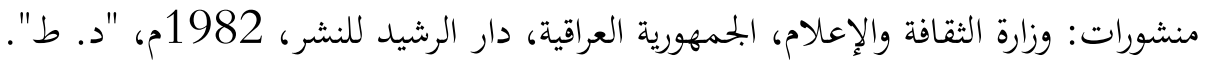
24- اللباب في علل البناء والإعراب، أبو البقاء عبد الله بـن الحسن العكبري، تحقيق غـازي

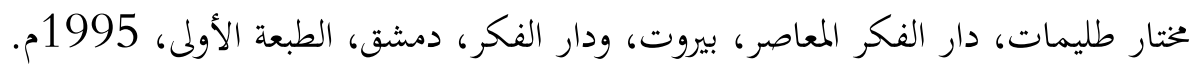

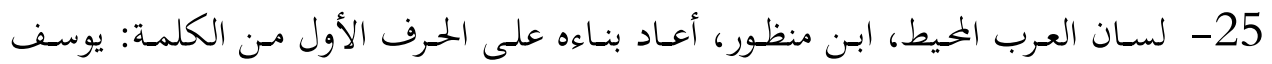
خيّاط، دار الجيل، بيروت، ودار لسان العرب، بيروت، 1988م، "د. ط".

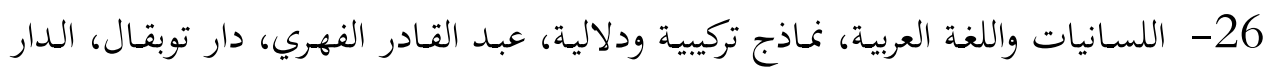
البيضاء، الطبعة الرابعة، 2000م.

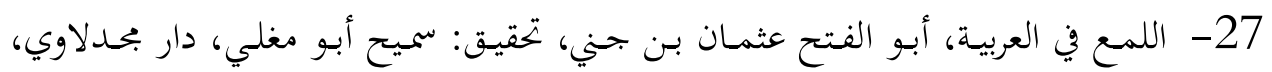

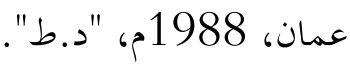
28- مجموعة الشافية من علمي الصرف والخطط، تحتوي المجموعة على: مـن الشافية وشرحها

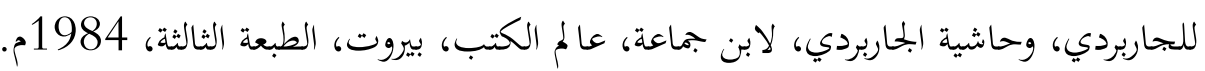

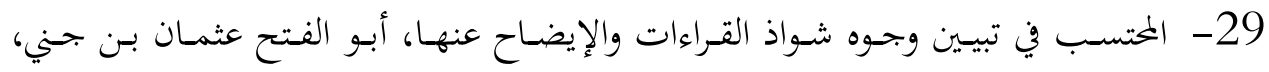
تحقيق: علي النجدي ناصف وعبد الفتاح إسماعيل شلبي، القاهرة، 1999م، "د.ط" لإِ

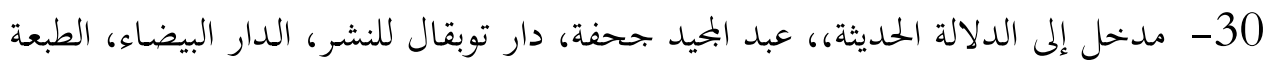
الأولى، 2000م. 31- المصطلحات التركيبة والدلالية في النحو التوليدي، أطروحة دكتوراة، صالح أحمد صافار، جامعة محمد الخامس، المغرب 2011م. 32- المعجم العربي العصري وإشكالاته، أحمد بريسول، وكنزة بن عمر، جامعة محمد الخامس-

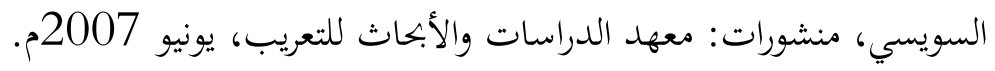


33- المعجم العربي المولد "إنشاء قاعدة معجمية عربية مولدة" إشراف: عبد القادر الفاسي

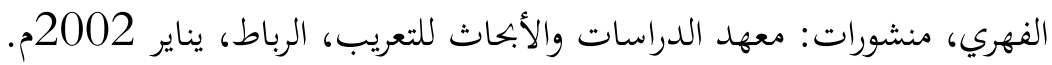

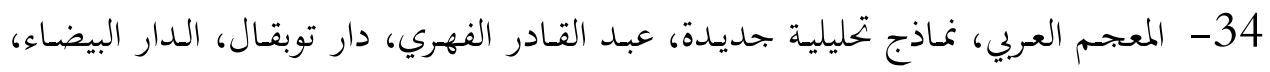

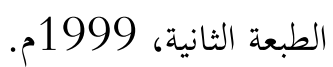
35- معجم المصطلحات اللغوية، إبحليزي، عربي، رمزي بعلبكي، دار العلم للملايين، بيروت،

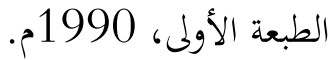
36- معجم مقاييس اللغة، أبو الحسين أحمد بن فارس، وضع حواشيه: إبراهيم شمس الدين،دار الكتب العلمية، بيروت، الطبعة الأولى، 1999م. 37- المعجمم الموحدد لمصطلحات اللسانيات "إبحليزي- فرنسي - عربي" المنظمة العربية للتربية والثقافـة، مكتـب تنسـيق التعريـب، مطبعـة النجـاح الجمديــة، الــار البيضــاء، الطبعـة الثانيـة، 2002 38- المعجم الوسيط، إبراهيم مصطفى، وأحمد الزيات، وحامد عبد القادر ـ ومحمد النجار، دار

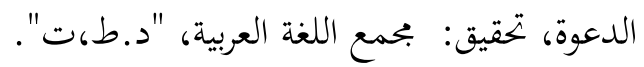
39- المَعْجَمَة والتوسيط، نظرات جديـدة في قضـايا اللغـة العربيـة، عبـد القـادر الفهري، المركز الثقافي العربي، الدار البيضاء، الطبعة الأولى، 1997م. 40- مغني اللبيب عن كتب الأعاريب، جمال الدين بن هشام الأنصاري، تحقيق: مازن المبارك،

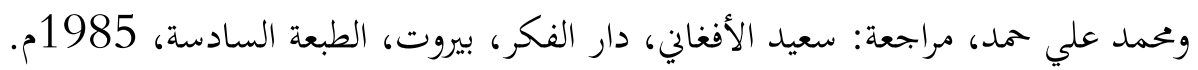
41- المفصل في صنعة الإعراب، أبو القاسم محمود بن عمر الزخشري، وبذيله كتاب المفضل دماريل في شرح أبيات المفصل للسيد محمد بدرالدين أبي فراس النعساني الحلبي، تحقيق: علي بوملحم،

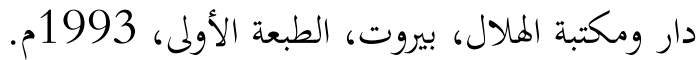

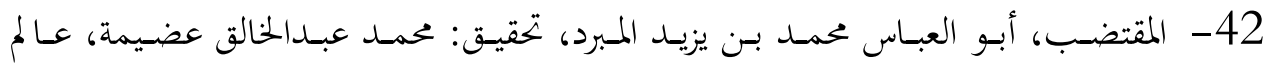

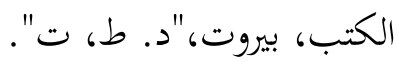


43- المقرّب، علي بن مؤمن المعروف بابن عصفور، تحقيق: أحمد عبد الستار الجواري وعبد الله

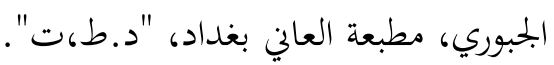
44- المنصف، شرح أبي الفتح عثمان بن جني لكتاب التصريف، لأبي عثمان المازين، تحقيق: إبراهيم مصطفى، وعبد الله أمين، إدارة إحياء التراث القليم، الطبعة الأولى، 1954م.

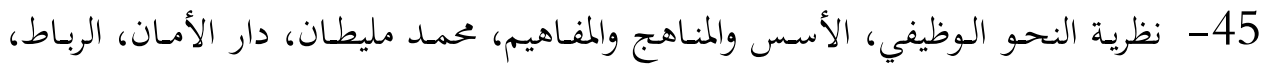
الطبعة الأولى، 2014م. - مكريه 46- النظرية النحوية، جيفري بوول، ترجمة:مرتضى جواد باقر، المنظمة العربية للترجمة، بيروت، الطبعة الأولى، 2009م. 47- نوادر الأصول في أحاديث الرسول -صلى الله عليه وسلم- محمد بن علي بن الحسن أبو

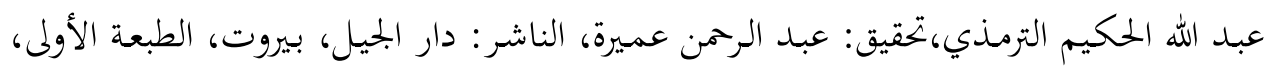
1992 48- همع الهوامع في شرح جمع الجوامع، جلال الدين السيوطي، تحقيق: عبد العال سالم مكرم،

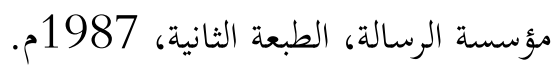

